Article

\title{
Measuring the Initial Social Sustainability Impacts of Estate Regeneration: A Case Study of Acton Gardens, London
}

\author{
Tim Dixon ${ }^{1, *}$, Nicola Bacon ${ }^{2}$, Lucia Caistor Arendar ${ }^{2}$, Emma Nielsen ${ }^{2}$, \\ Rosalie Callway ${ }^{1}$, Alix Naylor ${ }^{2}$ \\ 1 School of the Built Environment, University of Reading, Chancellor's Building, \\ Chancellor's Way, Whiteknights, Reading, RG6 6DF, UK \\ 2 Social Life, 12a Peacock Yard, Iliffe Street, London SE17 3LH, UK \\ * Correspondence: Tim Dixon, Email: t.j.dixon@reading.ac.uk; \\ Tel.: +44-0-118-378-7181.
}

\begin{abstract}
In the context of UK housebuilding this paper explores and critically reviews the initial measurement of social sustainability in the first phase of a new housing project on a large estate regeneration development in South Acton, London (conducted in March-April 2015). The research uses an existing "ex post" social sustainability framework adopted for use in other new UK housing projects and also examines local residents' attitudes to the first phase of the estate regeneration. The social sustainability assessment framework (created to reflect a UK housebuilder's perspective) is based on the analysis and comparison of a range of national datasets and interviews and survey work with new and existing residents and other stakeholders on the estate, and the surrounding areas. The research shows stronger ratings for a number of physical improvements in the new development, but weaker scores for local identity and links with neighbours. The research also shows a mixed picture in their attitudes towards the urban regeneration. The paper provides a critical discussion of the results and the framework, and concludes by setting out the lessons learned from the research for social sustainability assessment. The research will be useful for practitioners, housebuilders and policy makers involved in housing, and those with a wider interest in community wellbeing.
\end{abstract}

\section{G Open Access}

Received: 17 December 2018

Accepted: 13 March 2019

Published: 16 March 2019

Copyright (C) 2019 by the author(s). Licensee Hapres, London, United Kingdom. This is an open access article distributed under the terms and conditions of Creative Commons Attribution 4.0 International License.

KEYWORDS: housing; social sustainability; estate regeneration; community wellbeing

\section{INTRODUCTION}

In the UK, several housebuilders have attempted to highlight the importance of "social impact" through an active assessment and measurement of "social sustainability" on their housing developments [1-3]. This can be seen as part of the wider agenda of embedding "sustainable development" practices within housebuilding [2], and so 
recent academic and practice-based research in the UK has started to focus much more closely on social sustainability as a concept in the context of housing-led regeneration (and new build), and how it can be formally measured and assessed [4].

Over the last 20 years the concept of "social sustainability" has gained an increased focus in academic and policy discourse across a wide range of disciplines from science and engineering through to social science and the humanities [4-8]. However, although social sustainability was a key element within the overarching concept of "sustainable development" in the Bruntdland report of 1987, it was not until the late 1990s that social issues became a focus for discussion and debate within the sustainability agenda as previous research has acknowledged [6-8].

Over the past decade however, social sustainability has emerged as a field of research, policy and practice across a range of scales within housing and a wider built environment context in the UK [2,5,6,8-10]. Firstly, this has partly been driven by the institutionalisation of the concepts of "sustainable communities" (first introduced by the UK Labour government in 2003), "mixed communities" and "active citizenship", which have also created a "space" for the property and development sector to legitimise a range of flexible responses as to what "social sustainability" really constitutes in a built environment project [2]. This is particularly so, as "environmental sustainability" has become a "taken for granted" element in design and practice and no longer necessarily offers a competitive advantage for housebuilders, whereas social sustainability is seen by housebuilders as "unclaimed territory", offering a way of differentiation in a highly competitive market [2]. Secondly, some UK housebuilders (for example the Berkeley Group, Countryside, and Taylor Woodrow) have also attempted to highlight their credentials in "place-making", which links to recent urban "socio-spatial" planning discourse and the distinctiveness of places [10,11]. This is connected with a wider "sense of place" literature, and also the concept of "place-keeping", which highlights the idea of long-term stewardship of housing projects by housebuilders [1,11]. Finally, UK housebuilders are also being driven not only by the need to fulfil corporate responsibility requirements [12], but also the perceived "first mover advantage" in measuring and assessing social sustainability $[3,13]$.

Despite its multiple interpretations and a sense of ambiguity about the policy objectives, there appears to be a consensus in the literature that social sustainability incorporates a set of underlying themes that could be described as social capital, human capital and well-being [7,8,14-18]. Housing and urban regeneration are strong themes throughout this work, and also the notion that the neighbourhood (or local community) is an appropriate scale for measurement. Social equity and sustainability of community therefore underpin the broader "non-physical" aspects of social sustainability, allied with "physical factors" such as good design, decent housing and so on [8,14]. Importantly, this work also 
acknowledges that the practical and operational aspects of social sustainability are not well explored, clearly defined or well-integrated in the policy and practice of urban planning and housing [18]. Much of this previous research has primarily focused on existing housing at neighbourhood level and has frequently been concerned with linking social sustainability with urban form and density patterns. International examples of such work includes research in UK, Australia, New Zealand, Denmark and South East Asia [5,7,14,15,19,20].

There has also been a focus on developing a range of "ex ante" assessment tools to measure neighbourhood social sustainability before development has begun (for example, BREEAM Communities) [13,21], but little or no research on measuring social sustainability in new housing projects after construction has begun, or been completed (i.e., "ex post" or “downstream”) $[8,13]$.

The increasing focus on social sustainability in the UK comes at a time when a reshaped "estate regeneration" has itself become an important focus for government housing policy in England [22-27]. Estate regeneration is "the process of physical renewal of social housing estates through a range of interventions-from refurbishment and intensification, to demolition and rebuilding" [26]. Until relatively recently, urban regeneration policy in England since the 1990s had been characterised by an "area-based" approach with a substantial role played by the state, and implemented by local actors, often with multiple and imprecisely articulated objectives [22,23].

However, with the emergence of the coalition UK government in 2010 (and more recently a majority Conservative government in 2015), the emphasis has shifted further away from large-scale "urban regeneration" towards a formal policy intent of "estate regeneration" [23-27]. This, it is argued by the UK government (previously under David Cameron and subsequently under Theresa May), is a direct and appropriate response to the UK's urgent housing problem, often characterised as an affordability crisis [25,28]. It also resonates with the restructuring policies of large post-war housing estates in Europe [29,30].

Britain's local authority council estates have therefore moved centrestage again in government policy as the focus for a number of new private-sector led estate regeneration projects in London and elsewhere [31,32]. This essentially builds on the approach implemented by local government and housing associations before 2010, because the reduction in UK public sector resources for new housing and for regeneration and maintenance has propelled housing providers and housing managers to look to the private house building sector for additional capacity and resources [2,30]. For example, plans for significant estate regeneration schemes like Woodberry Down Estate in Hackney, Kidbrooke in south east London or the Aylesbury Estate in Southwark all originated in the 2000s. 
This approach to estate regeneration has generated opposition, however. For example, concerns have been articulated about the reliance on demolition and replacement rather than refurbishment [33]. There has been much anger (through activists such as "Architects for Social Housing") and accusations of "gentrification" and "social cleansing" criticism amongst some authors [31,32], particularly in relation to projects in London, where the charge has been made that residents of social housing estates have been displaced as a result of demolition and rebuilding (i.e., the "London clearances") [33,34]. In defence, supporters of the policy of "estate regeneration" suggest it can be used in a positive way to tackle problems of crime, deprivation and poor-quality housing [35]. This debate has also been played out against the backdrop of worsening affordability of housing in the UK, particularly London and the south east of England-for example in 2017, of the 10 least affordable local authorities in England and Wales, seven were in London [28].

This paper therefore explores and critically reviews the initial measurement of social sustainability (in the context of new house building) in the initial first phase of a large estate regeneration project by Action Gardens LLP (a partnership between L\&Q, Ealing Council and Countryside Properties) on the South Acton Estate in London during 2015. The focus is therefore on "ex post" assessment of the impact of new housing during the first phase of the project. The research focuses on (i) residents in the first phase of new housing development in the project, and (ii) the existing residents in the neighbouring area to the project. The paper firstly examines the development of a social sustainability assessment framework for measuring social impacts in an estate regeneration project; and secondly, also examines the overall attitudes of local residents towards the "estate regeneration" project during its initial phase. The framework is applied to the South Acton case study, and the results of this are described together with resident attitudes to the estate regeneration project. Finally, the paper provides a critical review of the results and the framework and concludes by setting out the lessons learned from the research for social sustainability assessment.

\section{METHODS}

The overall aim of this research was to assess the social sustainability of new housing in a large estate regeneration project (South Acton Estate, in the London Borough of Ealing) during its early phases, and to also examine how local residents felt in more general terms about the wider estate regeneration project. To achieve the first part of the aim and measure social sustainability, a framework was required which enables an assessment of views from both the new residents moving into the project, as well as the existing residents in the wider area. This can provide a more detailed picture of the estate regeneration programme; how people feel about opportunities to be involved in the decision- 
making process, and information about housing need and peoples' priorities for regeneration.

To develop the framework this research drew on previous work by Social Life [36] which was commissioned by the UK Homes and Communities Agency. This previous work had itself drawn on literature highlighted in the introduction to this paper, and therefore differentiates between "physical" factors (for example decent and affordable housing, access to opportunities, high quality public services, good public realm and good transport) and "non-physical" factors in social sustainability (for example, safety, local social networks, social inclusion and spatial integration, cultural heritage, sense of belonging and identity and wellbeing) (see for example [14]). The Social Life work [36] therefore suggested there were four main elements of social sustainability which were essential in building new communities. Firstly, "amenities and infrastructure", or the physical amenities and social infrastructure needed to be in place in the early life of a new community, with an emphasis on schools, social spaces, transport and community services. Secondly, "social and cultural life", relating to shared spaces, collective activities and the social architecture needed to develop and foster networks, belonging and local identity. Thirdly, "voice and influence", or the governance structures needed to help residents shape and influence local decision-making and stewardship. Fourthly, "space to grow", or the concept that places needed to have an inbuilt capacity for flexible planning, housing, infrastructure and services that can adapt over time.

Building on this work, social sustainability from a housebuilder's perspective was therefore defined in the following way [1]:

"Social sustainability describes the way a neighbourhood supports individual and collective wellbeing. It is about people's quality of life.

Social sustainability combines design of the physical environment with a focus on how the people who live in and use a space relate to each other and function as a community. It is enhanced by development which provides the right infrastructure to support a strong social and cultural life, opportunities for people to get involved, and scope for the place and the community to evolve".

This definition, which was developed by the current research team for a specific UK housebuilder, The Berkeley Group, therefore attempts to combine the physical and the non-physical aspects of social sustainability, by establishing a relationship between processes of change in the built environment, specifically regeneration and new housing development, and the creation of wellbeing, social capital and particular practices of citizenship at the neighbourhood level [2,12,16,18,36].

This framework was used in this research because it has successfully been applied in other contexts and was developed as an "open source" tool for the UK housebuilding industry [1]. Previous studies based on this framework were restricted to using surveys of residents within a scheme 
(including those in new and longstanding homes), but did not survey residents living outside the scheme, although the potential value of doing this has also been recognised [1,13].

It should be stressed that in this study the framework was not used to track a large sample of residents over a long period, but to provide a snapshot of community dynamics and quality of life at a particular point in time. Critically, it looked at the experiences of those households that are living in the older estate (in the buildings awaiting demolition) and those that have moved into the new homes. It did not assess the experiences or views of the residents who had lived on the estate but who may have been required to move away as a result of the regeneration (see discussion and conclusions).

This approach is therefore is not as robust as a large-scale longitudinal study would be in tracking detailed changes in communities and individuals (including the potential displacement of residents [13]). This constraint, together with the focus on the early phases of regeneration, therefore meant a detailed displacement analysis of existing residents was not possible during this initial analysis.

The focus of the framework, and the starting point for the measurement of social sustainability, is on the aspects of community strength and quality of life that a house builder could "reasonably" be held directly accountable for or could influence through relationships with public agencies. This means that some dimensions of social sustainability are not represented in this framework; for example, measures focused on justice and access to employment (in contrast to some other approaches [31]). These elements have been excluded because they have been defined as being "outside the remit" of the housebuilder [1]. Moreover, "space to grow" was also omitted as a discrete element. However key questions about adaptability of space and facilities and residents' ability to influence future change were included within other dimensions: the physical aspects of space to grow were included in "amenities and infrastructure" and the ability to shape and influence a place were included in "voice and influence", given that in discussion with house builders it was felt that this was a more appropriate way to capture these elements.

The final framework (Figure 1) was based on the framework developed for the Berkeley Group [1] by the research team and was also applied to a wider geographic area outside the development itself. The framework therefore incorporated three main elements:

1. "Amenities and infrastructure", which captures past and planned attempts to lay the foundations for a thriving community through housing mix, public realm, landscaping, transport connections and community infrastructure.

2. "Social and cultural life", which illustrates the present, how people experience the development and how this contributes to their quality 
of life, perceptions of safety, feelings of belonging and interaction with neighbours.

3. "Voice and influence", which illustrates residents' potential to shape their future through opportunities to engage and influence the built environment and shape their everyday lives.

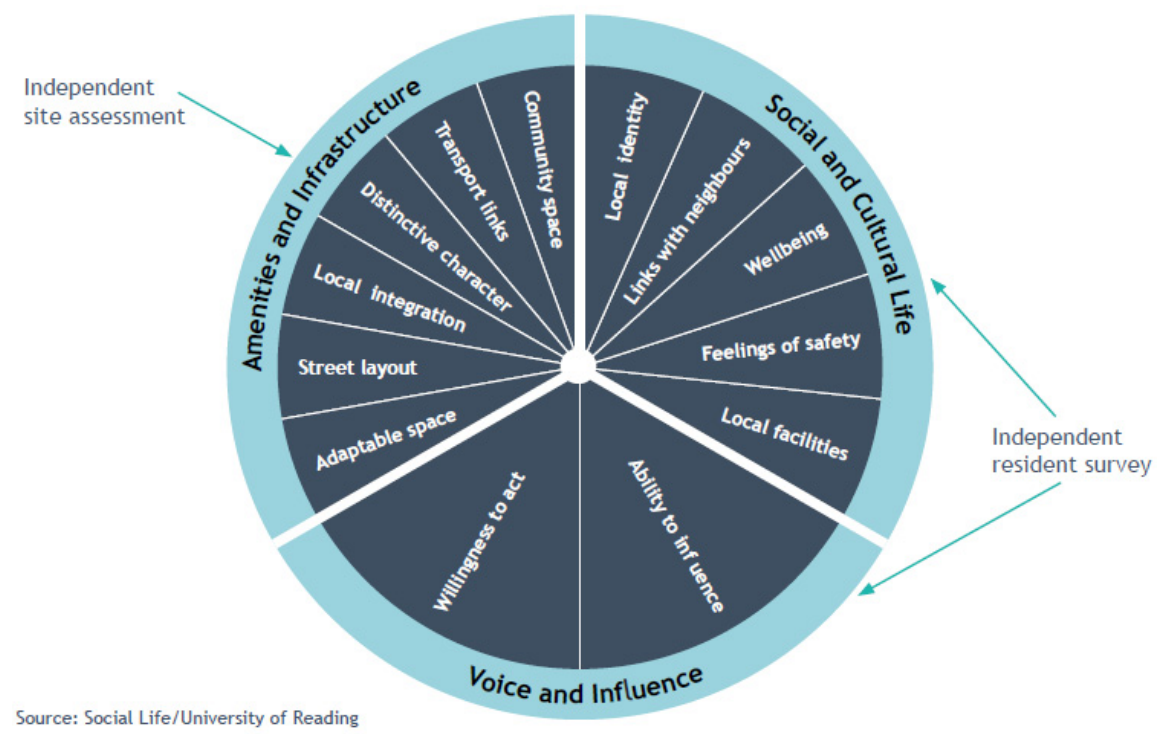

Figure 1. The Berkeley Group social sustainability measurement framework [1].

To operationalise the framework, the three different dimensions incorporated 13 different indicators (Table 1). Each indicator is informed by a number of different questions, as shown in the column headed "benchmark data". The full set of questions used in the household survey which underpins this part of the research is shown in Appendix 1.

Table 1. Social sustainability indicators (adapted from [1]).

\begin{tabular}{|c|c|c|c|}
\hline $\begin{array}{l}\text { Component of } \\
\text { social sustainability }\end{array}$ & Focus & Indicators & Benchmark data \\
\hline $\begin{array}{l}\text { “Amenities and } \\
\text { infrastructure” }\end{array}$ & $\begin{array}{l}\text { Past and planned attempts to lay the } \\
\text { foundations for a thriving community } \\
\text { through housing mix, public realm, } \\
\text { landscaping, transport connections } \\
\text { and community infrastructure }\end{array}$ & $\begin{array}{l}\text { Community space; } \\
\text { transport links; } \\
\text { distinctive character; } \\
\text { local integration; street } \\
\text { layout; adaptable space }\end{array}$ & $\begin{array}{l}\text { Based on structure } \\
\text { and scoring system } \\
\text { of the CABE Building } \\
\text { for Life survey }\end{array}$ \\
\hline $\begin{array}{l}\text { "Social and cultural } \\
\text { life" }\end{array}$ & $\begin{array}{l}\text { Illustrates the present, how people } \\
\text { experience the development and how } \\
\text { this contributes to their quality of life, } \\
\text { perceptions of safety, feelings of } \\
\text { belonging and interaction with } \\
\text { neighbours }\end{array}$ & $\begin{array}{l}\text { Local identity; links with } \\
\text { neighbours; wellbeing; } \\
\text { feelings of safety; } \\
\text { community facilities }\end{array}$ & $\begin{array}{l}\text { Understanding } \\
\text { Society } \\
\text { Community Life } \\
\text { British Crime Survey }\end{array}$ \\
\hline $\begin{array}{l}\text { "Voice and } \\
\text { influence" }\end{array}$ & $\begin{array}{l}\text { Residents' potential to shape their } \\
\text { future through opportunities to engage } \\
\text { and influence the built environment } \\
\text { and shape their everyday lives }\end{array}$ & $\begin{array}{l}\text { Willingness to act; ability } \\
\text { to influence. }\end{array}$ & $\begin{array}{l}\text { Understanding } \\
\text { Society } \\
\text { Community Life } \\
\text { British Crime Survey }\end{array}$ \\
\hline
\end{tabular}


This approach was chosen to ensure that the resident survey and site survey used pre-tested and validated questions, and that the resident survey findings could be benchmarked against national datasets. The rationale for incorporating pre-existing questions was twofold: firstly, they have already been tested and validated; and secondly, they enable comparisons between the experience of residents in a specific neighbourhood and other similar areas. The results of the household survey were then compared with responses to the same questions in three large-scale national surveys (see also Table 1 and Appendix 1):

- Understanding Society, the UK's largest, longitudinal household panel survey with 40,000 participating households (2011-12)

- Community Life, an annual survey based on approximately 6000 face-to-face interviews (2012-13)

- British Crime Survey, an annual survey of 35,000 people (2011-12).

The benchmarking method uses the Office for National Statistics' Output Area Classification (OAC) and Index of Multiple Deprivation (IMD) classifications to identify the average responses for areas that share the same OAC social profile and IMD ranking. This approach enables comparison between the average responses of people living in the South Acton Estate and Acton Gardens, to the benchmark, which are the average responses of people with a similar profile in comparable areas. The differences between the actual and expected scores are subjected to statistical testing. These results are then used to populate the voice and influence and social and cultural life dimensions of the framework. These benchmarks are referred to as the "benchmarks for comparable places".

To test whether responses from residents were different from the comparable area, a statistical $z$ test for difference in proportions was carried out, with the survey questions as dependent variables (specifically the percentage answering positively to each question), and whether respondents were residents, or part of national or comparable place groups, as the independent variable. For each level of comparison, analysis of national and comparable place groups was carried out, selecting only those individuals that were members of the required comparison group.

To give an example of this, Table 2 shows an extract of the relevant data for the questions relating to "local identity" in Acton Gardens Phase 1 and the South Acton estate.

The $z$ test is a statistical test which determines whether or not there is a significant different between two scores-in this case the difference between two percentages. It calculates how large the difference is in terms of standard deviation from the mean (in this case a "pooled percentage" of both groups). If the result of the $z$ test is more than \pm 1.96 this indicates the difference is significant at the 95\% confidence level (equivalent to a $p$ value of 0.05 or less). This figure comes from the $\mathrm{z}$ 
distribution (often referred to as a bell curve) where the mean is 0 and the standard deviation is 1 and $95 \%$ of the distribution falls between -1.96 and 1.96 standard deviations from the mean.

Table 2. Example of benchmark scores (local identity criteria for Acton Gardens).

\begin{tabular}{|l|c|c|l|c|}
\hline Question & $\begin{array}{l}\text { Positive responses } \\
\text { in Acton Gardens } \\
\text { Phase 1 }\end{array}$ & $\begin{array}{l}\text { Positive responses } \\
\text { in national } \\
\text { comparable areas }\end{array}$ & $\begin{array}{l}\text { Difference in } \\
\text { comparable } \\
\text { place }\end{array}$ & $Z$ score \\
\hline $\begin{array}{l}\text { Plan to remain resident of } \\
\text { this neighbourhood for a } \\
\text { number of years }\end{array}$ & $80.5 \%$ & $51.4 \%$ & $29.1 \%$ & 3.69 \\
\hline $\begin{array}{l}\text { Feel like I belong to this } \\
\text { neighbourhood }\end{array}$ & $61.0 \%$ & $58.1 \%$ & $2.9 \%$ & 0.37 \\
\hline
\end{tabular}

In Table 1 therefore we can say that there is a significant positive difference in the plan to remain in the neighbourhood for Acton Gardens residents, compared with comparable places $(z$ score $=3.69)$. For the other question the difference is not significant $(z$ score $=0.37$ ). The results of the household survey and statistical testing can then be reported using a simple graphic rating. Responses that are significantly more positive than the benchmark are reported in green as being better than average. Responses that are significantly less positive than the benchmark are reported in orange as being worse than average and responses in line with the benchmark, or the same as the national average, are reported in dark blue (The full scoring system is explained in Appendix 2 and full results are given in Appendix 3).

The results for the "amenities and infrastructure" dimension of the framework were based on the site survey, which adapts the structure and scoring system of the Design Council CABE Building for Life survey which is the industry standard for the design of new housing. The site survey assesses the six indicators in the Amenities and Infrastructure dimension of the research framework: community space; transport links (including Public Transport Accessibility Level (PTAL)); distinctive character; local integration; street layout and adaptable space. This indicator is not benchmarked against national survey results in the same way as the other indicators from the household survey, because there is no appropriate national survey data for comparison. However, the Building for Life scoring approach is well documented with site assessors receiving training in this approach, and therefore scores have some constancy with similar developments. The scores were "normalised" to produce scores which either fall below, meet or exceed the standard (see Appendix 1 and Appendix 2 for further details on the site survey and scoring system respectively). 


\section{RESULTS-CASE STUDY OF ESTATE REGENERATION: SOUTH ACTON ESTATE (EALING, LONDON)}

\section{Case Study Background and Context}

The South Acton Estate is the largest council estate in the London Borough of Ealing with over 1800 homes (Figure 2). The estate was originally a Victorian estate of terraced houses, but was then redeveloped over a 30-year period after the Second World War. The southern and northern parts of the estate have quite different characteristics. The southern area (to the south and west of Osborne Road) dates from the 1960s and is fairly typical of its era, whilst the northern part of the estate, a series of mid-rise brick-clad slab blocks interconnected by walkways and raised podia dates from the late 1970s. This area also contains some free-standing towers, one of which was used for filming the popular BBC TV series, Only Fools and Horses [37]. In 1999, Ealing Council began a major regeneration programme following consultation with the community. It was decided to comprehensively regenerate the area, and this was seen as the best way to transform the area from the point of view of both residents and council. The master plan includes the redevelopment of all the existing homes, which will be replaced with 2517 new homes, built in 21 phases between 2011 and 2024 . At the time that the research was carried out the plan was that over half of the homes will be affordable (with over $70 \%$ of these as social rented properties, and the rest shared ownership), and the majority of existing residents with secure tenancies will move to new homes once they have been built.

The South Acton Estate estate regeneration programme is also highlighted as an example of "best practice" in the government's estate regeneration strategy [25,27].

\section{Case Study Approach}

Data to inform the "social and cultural life" and "voice and influence" dimensions was gathered through a face to face survey of residents (households), and data to inform the "amenities and infrastructure" dimension was gathered through a site survey. The residents' survey also gathered data on residents' general attitudes to the estate regeneration which are reported in this paper, but this part of the survey did not feed into the social sustainability assessment. The questions for this part of the survey are provided in Appendix 4 to this paper. A small number of additional interviews with stakeholders were also carried out to provide broader context for both dimensions of the work. All the interviews and site survey work were conducted in March-April 2015. The face to face residents' survey work and site survey are now discussed in detail. 

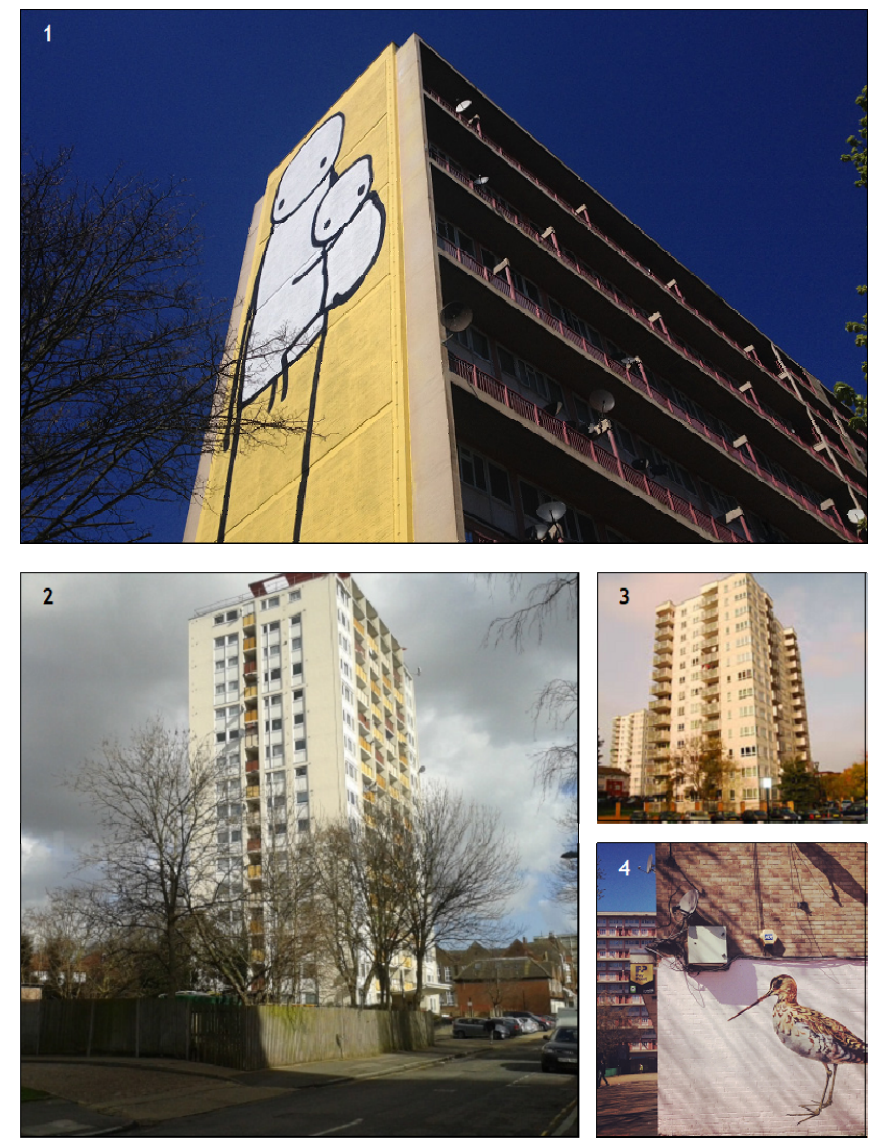

Figure 2. South Acton Estate at the time of the research. (1) "Big mother" by street artist Stik; (2) South Acton Estate (West London Film Office); (3) South Acton Estate (Ealing in London); (4) Acton Estate.

\section{Residents' survey}

To gather the relevant data from residents, 544 people were interviewed in a face to face household survey of South Acton Estate, Acton Gardens (Phase 1-new housing development) and the streets surrounding the estate. A random sampling method and tenure-based quotas were used to design the research, to ensure that the overall number of interviews reflects the tenure composition of each area and cluster (see Table 3). The household survey was conducted during three weeks in March and April 2015, with interviews during the day, in the evening and at weekends. Where buildings were empty ready for demolition, no interviews were able to be carried out.

Table 3. Household survey composition.

\begin{tabular}{|l|l|l|}
\hline South Acton Estate and Phase 1 Acton Gardens & Number & Percentage \\
\hline Council tenants & 203 & $69 \%$ \\
\hline Privately owned (or rented) & 67 & $23 \%$ \\
\hline Housing association & 20 & $7 \%$ \\
\hline Other & 3 & $1 \%$ \\
\hline Total & 293 (252-South Acton Estate; & $100 \%$ \\
& 41 -Acton Gardens) & \\
\hline
\end{tabular}


Table 3. Cont.

\begin{tabular}{|l|l|l|}
\hline Wider Area (all three clusters) & Number & Percentage \\
\hline Council tenants & 24 & $10 \%$ \\
\hline Privately owned (or rented) & 218 & $87 \%$ \\
\hline Housing association & 6 & $2 \%$ \\
\hline Other & 3 & $1 \%$ \\
\hline Total & 251 & $100 \%$ \\
\hline
\end{tabular}

The household survey was conducted in two main areas (Figure 3):

- Sample Area 1-South Acton and Phase 1 Acton Gardens: 252 people on the South Acton Estate (211 in three "clusters" of existing properties on adjoining streets (centre, west and Redbricks) and 41 people living in new Phase 1 housing Acton Gardens were interviewed (of whom 17 had lived in the estate previously)).

- Sample Area 2-The Wider Area, where interviews were conducted in the existing streets and houses surrounding the South Acton Estate, selected on the basis of a 5-minute walking radius from the centre of the estate. These comprised three areas: Mill Hill conservation area; Acton Town; and Acton Green.
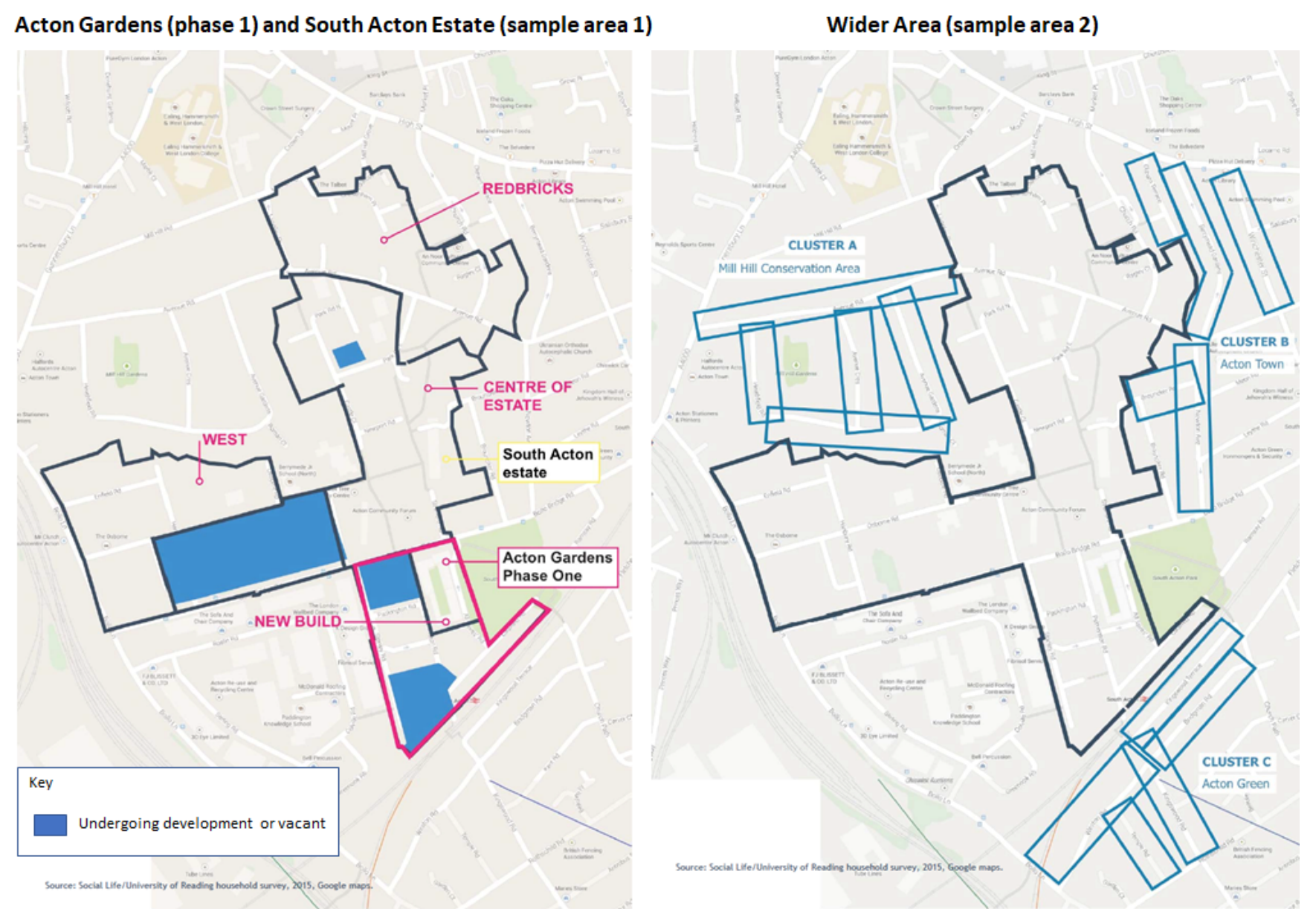

Figure 3. South Acton: Sample Areas 1 and 2. 


\section{Site survey}

An independent site survey was carried out by an architect to assess the quality of the built environment and the provision of local community facilities on the South Acton Estate and in Acton Gardens. The site survey assessed the six indicators within "Amenities and Infrastructure": community space; transport links; distinctive character; local integration; street layout and adaptable space. The survey was based on questions from the Design Council CABE's Building for Life assessment tool, with some additions, which is the industry standard for the design of new housing. The assessment is based on a site visit undertaken in March 2015, and was supported by analysis of various planning documents relating to the regeneration programme. Empty existing buildings (vacant because of the decanting and demolition process) were not assessed in the site survey.

\section{Contextual interviews}

Ten further semi-structured 30-90 minute face-to-face interviews were conducted with community representatives (mainly long-term residents from the local area) for additional insights into the estate regeneration, and a number of local organisations and service providers based in, or supporting people living in, South Acton.

The findings of the social sustainability assessment and the residents' attitudes towards the estate regeneration are now presented in detail.

\section{Results and Main Findings from Case Study}

\section{Social sustainability}

The overall scores for Acton Gardens Phase 1 (new housing) and the existing South Acton Estate are shown in Figure 4 and the full results for social and cultural life and voice and influence which underpin the two diagrams are provided in Appendix 3. The results are now explored in more detail.

Amenities and infrastructure. Although we are unable to include the CABE source data because it is a confidential survey, the Amenities and Infrastructure indicators derived from the site survey show that overall Acton Gardens receives a higher rating (four green segments) than the South Acton Estate (two green segments).This broadly reflects the improvements to housing design and public realm as a result of the first phase of the estate regeneration (Figure 4). Acton Gardens therefore scores positively for four of the indicators-transport links, distinctive character, local integration and street layout. However, Acton Gardens is given an average assessment for community space compared to the positive assessment for South Acton Estate. This reflects both the wide range of well-used community facilities, play spaces and public areas on the existing estate, but also concerns that centralising local services in the new plaza and community hub in the future may impact negatively 
on people living in the further reaches of the estate. Both Acton Gardens and South Acton Estate are given a negative assessment for adaptable space and South Acton Estate is given a negative assessment for street layout, reflecting the comments about the estate's complex form that is often disconnected from street networks and other buildings.

\section{Acton Gardens Phase 1}

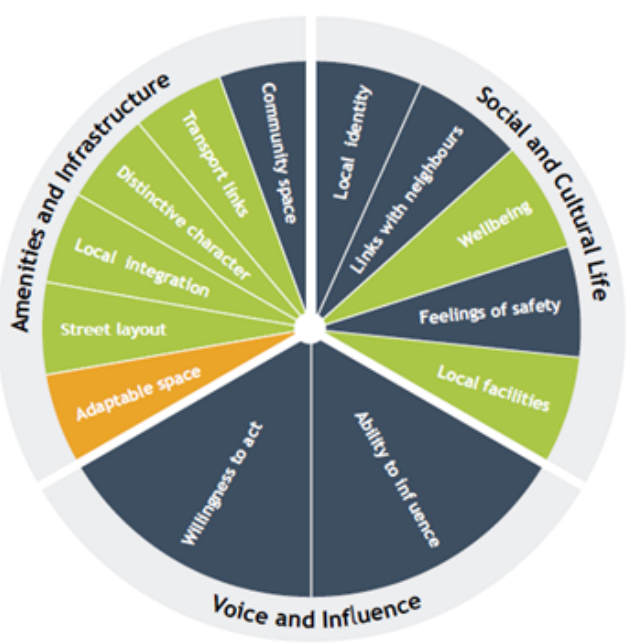

South Acton Estate

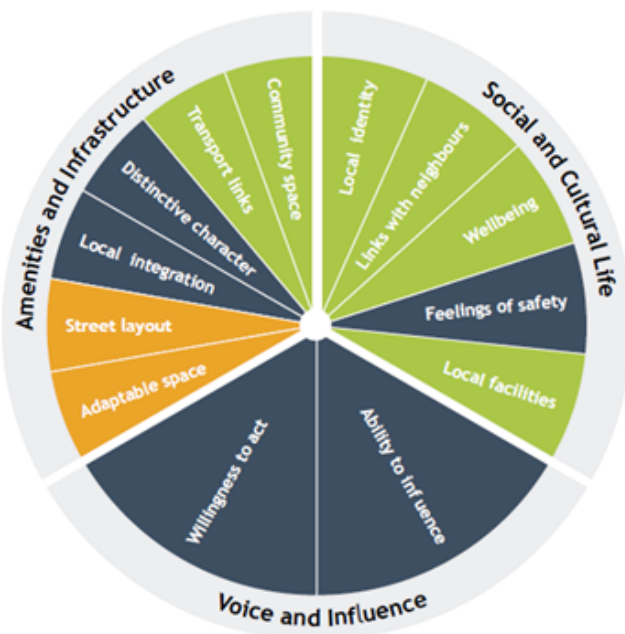

Figure 4. Benchmarking Acton Gardens (Phase 1) and South Acton Estate.

The key findings from survey work show that based on the site survey, the first phase of development at Acton Gardens has therefore improved the public realm, quality of housing and integration with the wider neighbourhood. It was also clear that Acton Garden's more "traditional” new urban design arrangement of doors on streets, consistent layout and high maintenance of streets, has improved way-finding compared to the existing South Acton Estate.

South Acton Estate was found at the time of the survey to offer a good mix of community spaces and local services to residents, which are currently scattered throughout the estate, but it was also felt by respondents that centralising these services in the new community hub may impact negatively on people living in the further reaches of the estate, and also raised the challenge of accommodating local organisations that offer informal but important support services to the community. Both the South Acton Estate and Acton Gardens received a negative assessment for the adaptable space indicator at the time of the research. The shared courtyards in Acton Gardens seem to be controlled in use and the landscaping is prohibitive to ad hoc uses and adaptions.

Both South Acton Estate and Acton Gardens received a positive assessment for transport links. South Acton rail station to the south, Acton Centre to the north and Acton Town underground station mean that all parts of the estate are within easy reach of the main transport network. In the southern part of the site, roads penetrate the estate and 
there are numerous, new and well-served bus stops. On the South Acton Estate, the Public Transport Accessibility Level (PTAL) varies from 5 to 6 (maximum) falling to 3 on the north-east edge of the estate.

Social and cultural life. South Acton Estate (four green segments) received a more positive assessment than Acton Gardens (two green segments) for measures relating to Social and Cultural Life, scoring higher on "local identity" and "links with neighbours" (Figure 4 and Appendix 3). This means that residents who took part in the household survey gave responses to these questions that are significantly more positive than the average for the comparable area. For example, the existing community demonstrates a higher level of "belonging" than the new residents: 84\% of people living on the South Acton Estate and 85\% of people in the wider area said they expected to stay on the estate for a number of years, compared with $80 \%$ of Acton Gardens residents (Figure 5). Similarly, $86 \%$ of people in the estate felt they "belonged" compared with $61 \%$ in Phase 1 of Acton Gardens. It is possible that this is because new residents have not yet built the social bonds and neighbourly relations which characterise the older estate.

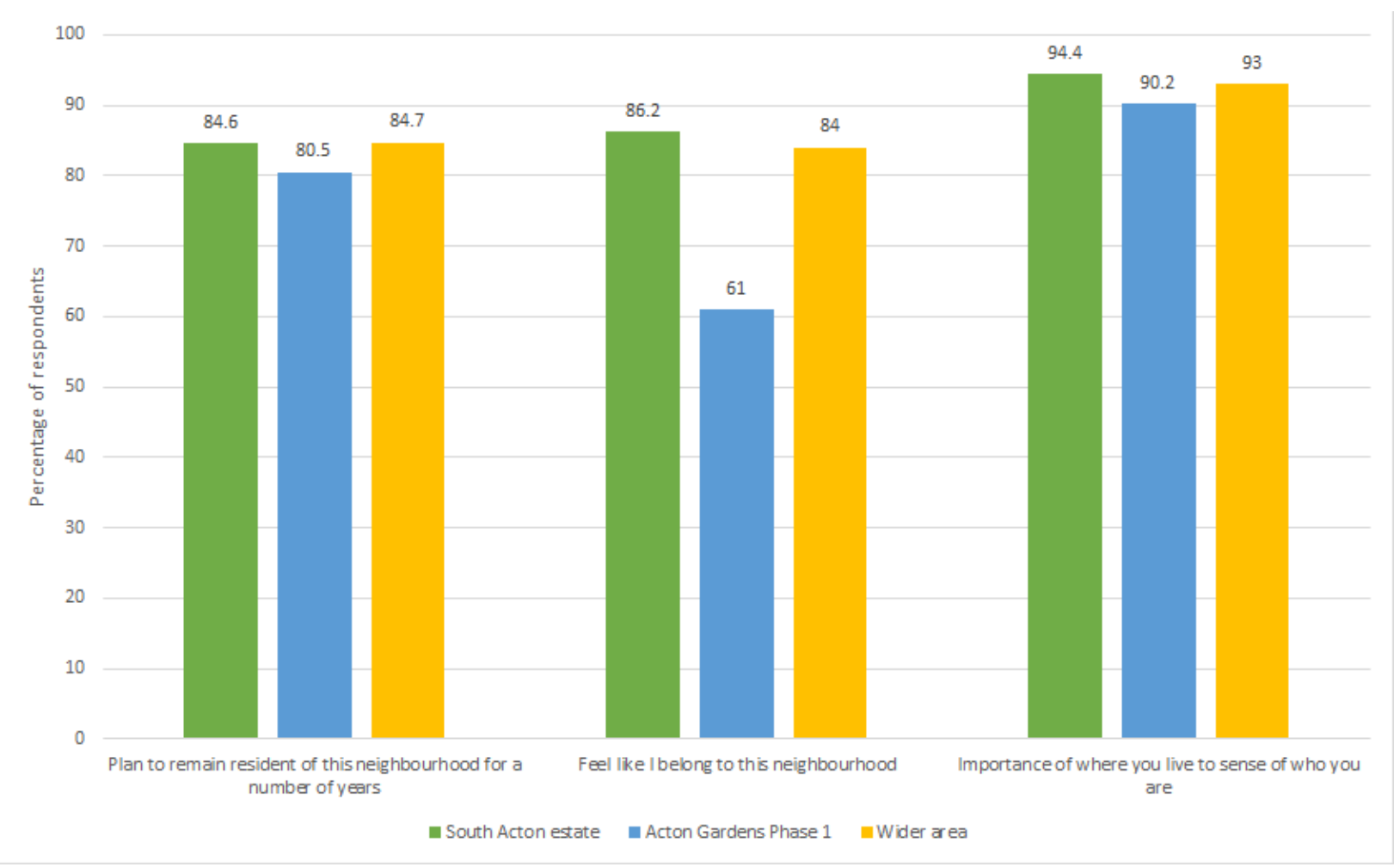

Figure 5. Sense of local identity (Respondents to question = 539).

Many people who took part in the contextual interviews commented on the strong existing sense of community on the South Acton Estate. Interviewees felt that residents tend to look after one another and feel part of a wider community. One of the interviewees gave the example of a block, which is now vacant, where "there was... a togetherness...it was like a family". Some interviewees described the estate as resilient but also 
quite a closed community: in one instance, where people from different backgrounds are tolerant of difference but tend not to interact very much with people from different cultural or ethnic groups. In another interview, one of the youth workers described their perception that opportunities for young people are limited and some young people say they feel "trapped".

People described how different communities had moved to South Acton Estate in waves and have now settled. For example, interviewees mentioned how the first council tenants who moved to the estate in the late seventies and early eighties were mainly Irish and Caribbean families, followed by many Somali families in the nineties, many coming to flee the civil war. Newer migrants have settled on the estate from various countries including many from Eastern Europe. One resident listed over 15 different nationalities found in their tower block including Armenian, Nigerian, Moroccan, Lebanese and Greek people. Several people described a general feeling that South Acton residents display high levels of tolerance, but that integration is low. As one person working in a local organisation said: “...there's a lot of really good stuff here...it's amazingly tolerant”. However, other respondents felt that not enough is being done to integrate new residents and create opportunities for people to mix.

The contextual interviews with people living and work on the estate identified a sense of pride in the neighbourhood, and a feeling that things are improving. There is a perception that how the estate is perceived from the outside no longer reflects the reality. There is a recognition and some frustration that it is taking time for the reputation of the estate to improve in the wider area.

Nonetheless, people who took part in the contextual interviews also said that today they generally felt "safe" in the area. The South Acton Estate used to have a bad reputation; but levels of crime have dropped, and there is a sense that people feel much safer in the local environment because of the estate regeneration. However, interviewees acknowledged there are still problems with crime, particularly with drugs and gangs, although these issues are being managed by local service providers. A lack of integration with the wider neighbourhood was felt to be partly due to the difference in urban fabric from the surrounding areas and the lack of permeability through the estate.

Voice and influence. Both Acton Gardens and South Acton Estate receive an average assessment for the Voice and Influence indicators as represented by the two blue segments in each benchmark "wheel" (Figure 4). These indicators show how residents describe their own involvement in, and their feelings about how they can influence, local decision-making; and their willingness to work with other people locally to improve the neighbourhood. This result means that residents of Acton Gardens and the South Acton Estate are no more or less likely to be 
involved in, or to feel they can influence, local decision-making than people living in comparable areas.

However, there were some interesting differences within the survey. People living in the wider area reported much higher levels of feeling they are able to influence decisions affecting their local area: $88 \%$ said they agreed or tended to agree that they have influence, compared to $48 \%$ of South Acton residents, and 30\% of Acton Gardens residents, which perhaps reflects the fact that many of the latter are new residents. People living in the wider area were also much more likely to want to influence local decision-making. 88\% of people interviewed from the wider area said it was quite or very important to them compared to $87 \%$ in Acton Gardens, and 73\% of people living on the South Acton Estate.

People living in Acton Gardens Gardens Phase 1 (new residents) also reported a lower level of willingness to work with other people to improve the local neighbourhood (66\%) compared to the South Acton Estate (84\%) and the wider area (87\%). The majority in all three areas believed that the neighbourhood pulls together to improve the area, South Acton Estate (83\%), Acton Gardens (78\%) and wider area (91\%).

\section{Attitudes towards estate regeneration}

In the household survey, the questions relating to the estate regeneration explored the importance of being able to influence estate regeneration; knowledge of the regeneration programme; and their feelings about the estate regeneration. The results were not compared statistically in the regeneration survey as we were only interested in overall responses to the regeneration and the sample size is relatively small, making intra-group comparisons more difficult.

Residents' influence and knowledge about regeneration. Overall, $69 \%$ of the 544 people interviewed said it is "quite" or "very" important to them to feel they can influence decisions about the regeneration programme, with the highest proportion of these being those in Acton Gardens (83\% of these respondents). However, people's knowledge of the regeneration programme was relatively lacking. Overall, 39\% of the people who were surveyed said they know a lot or have some information about plans to regenerate the South Acton Estate. In the past 12 months $89 \%$ had received the Acton Gardens quarterly newsletter about the regeneration, $86 \%$ had read the newsletter, and $15 \%$ had attended meetings or events to provide residents with information about the regeneration project. Unsurprisingly, people living on South Acton Estate and Acton Gardens knew more about the regeneration than people living in the wider area.

Residents' feelings about regeneration. The survey included openended questions to examine how residents felt about regeneration:

- From what you know about the regeneration plans, what do you think about them? 
- How did you feel about the Acton Gardens regeneration project before you moved to your new home?

- Can you tell me how you currently feel about the Acton Gardens regeneration project?

- Overall, what three factors about living in this neighbourhood contribute most to your quality of life?

When asked about what they felt about the regeneration plans, less than $40 \%$ of people surveyed in Acton Gardens and on the South Acton Estate gave an "overall positive" response. More people in the West area were positive (37\%) than the other areas and the smallest number of positive responses came from the Redbricks area (27\%). This comment from a resident living in the centre of the estate is typical of the positive comments about the regeneration, many of whom described improvements to the public realm and housing: "Firstly, the area will be neat and tidy and attractive. It will bring new life to the community as a whole".

Just over $17 \%$ of people living in Acton Gardens commented on the good design of the new housing. Some of the open-ended comments about design included statements such as: "It's good because it changes the structure of the place" (resident in the centre of the estate) and "I like the idea. It definitely needs to be redeveloped and some of the properties I have seen around here are in dire need of modernisation" (Redbrick resident). However, only a very small number of people from elsewhere on the Estate made comments about design. A small number of people who were surveyed also knew nothing about the regeneration process.

However, a minority (12\%) of Acton Gardens residents were more negative about the regeneration. One respondent stated: "II] feel concerned for the future of the area and the housing of the existing tenants without distraction to family and schools". Some stakeholders described how they thought some residents did not have the information they needed to be able to make an informed decision about whether they should be re-housed in Acton Gardens and become a housing association tenant or whether they should move elsewhere. For example, one stakeholder commented: "They're asking us to make a choice, but we have no idea what we're being offered"; and "Not knowing what is going on is the worst".

This raises the important issue of displacement of existing residents in such estate regeneration projects. The estate is still (at the time of writing) in the early phases of redevelopment, so it was not possible to examine the displacement of residents in the same detail as other research in this field has done [13,31].

The programme has a "right to remain" policy in place, which means that social housing tenants with secure tenancies who need to move as part of the regeneration programme are offered the choice of moving to a new home being built on the South Acton estate, or an alternative Ealing Council property outside the estate [38]. Some $62 \%$ of secure 
Ealing Council tenants have opted to move into a new L\&Q property within Acton Gardens to date. However, this does not include existing Ealing Council leaseholders who have opted to buy a shared equity property with L\&Q, or residents who moved as part of the early regeneration (and for which data is currently unavailable). The number of residents choosing to remain living in South Acton has also increased in the past two years, with $85 \%$ of secure tenants in the latest block due to be demolished (Webb Court) opting to move into one of the new homes being built on Acton Gardens [38,39]. Additionally, 360 leaseholders have been offered the option of either owning a new property on the estate, through a shared equity lease, or being offered full market value for their current property with an additional 10\% compensation [39]. However, it should be noted that the shared equity scheme is offered to existing resident leaseholders who have community links to the area, rather than landlords who rent their homes for commercial purposes: therefore, not all 360 leaseholders would be eligible for this scheme. To date (2018), 12 former resident leaseholders have purchased a shared equity property (phases 1-3). Ealing Council and Acton Gardens LLP have also supported tenants of private leaseholders to find alternative accommodation within the area, including property searches and financial support (i.e., paying deposits on alternative properties through discretionary home loss payments to these families). Further research, however, is needed to analyse the displacement in detail.

In the contextual interviews, however, people reported that the emptying out of the estate during regeneration is having an impact on the activities in the community. There was some ambivalence about the impact of a more affluent population moving into the area with respondents suggesting it could be positive for the area, whereas others said it could cause tensions. Most people were more concerned about whether existing residents would be able to remain on the estate.

Interviewees also raised concerns that new space for community organisations will mean rent rises and greater pressures at a time when many of these services are already uncertain about their future, as well as possible loss of existing premises which have been carefully arranged to meet users' needs.

\section{DISCUSSION}

This research has applied a framework to assess and measure social sustainability on the first phase of a new housing development, as well as the social sustainability of the wider estate. The framework analysed the social sustainability of a housing estate undergoing regeneration based on three main dimensions: (i) amenities and infrastructure; (ii) social and cultural life; and (iii) voice and influence. This framework attempted to combine the design and community aspects of social sustainability (focusing primarily on the community strength and quality of life in the 
estate), and used a technique based on benchmarking responses to survey questions linked to UK national datasets. The comparison of the three dimensions between the first phase of the development and the wider South Acton estate showed stronger ratings for a number of physical improvements in Phase 1 of Acton Gardens, reflecting the initial improvements to the estate, but weaker scores for local identity and links with neighbours, possibly reflecting the fact that some of the residents to Acton Gardens are relatively new to the area.

The South Acton case study is therefore an important example of estate regeneration in London during its initial phases. The additional interview survey questions of residents about the estate regeneration identifies a community in South Acton where people from a wide variety of different backgrounds feel like they belong and benefit from good local services. Some residents do seem to recognise that regenerating local housing and the public realm is much needed to improve the South Acton Estate (and its immediate surroundings) as a place to live, particularly to tackle over-crowding and poor-quality housing, and to build on recent work to improve safety. However, people also recognise the success of the regeneration programme requires more than changes to the physical environment. Moreover, attitudes towards the estate regeneration are somewhat "mixed", with some interviewees expressing reservations about possible displacement of existing residents and gentrification. A coherent and reflexive approach to understanding and tackling underlying social and economic issues is therefore needed, and a key aspect of this approach is recognising and valuing the less visible and less tangible aspects of social life in South Acton. Understanding the role that local relationships play in supporting community wellbeing, and finding ways to protect and nurture these networks as people are re-housed will be an important factor influencing the long-term social outcomes of the regeneration programme, including potential displacement of residents.

The application of the social sustainability framework is also subject to several limitations. Firstly, it should be appreciated that the definition of social sustainability on which the framework is anchored is very specific and is linked to those elements which a housebuilder could directly be accountable for or could influence through partnerships with public agencies [1,2,13]. There may also be tensions between the outcomes of the social dimension and economic and environmental sustainability which need to be monitored. It is therefore a particular perspective on social sustainability which is highly mediated and relies on the selective inclusion of policy goals and professional practices to make it operational.

Secondly, the focus on the early stages of the estate regeneration have also meant it was not possible to assess the displacement of existing longer-term residents across tenures, or to track and monitor social sustainability over time. Further research, is needed to analyse the 
displacement in detail as the rest of the estate regeneration project is rolled out.

Thirdly, this also raises the issue of longitudinal measurement of social sustainability. As the South Acton estate regeneration project progresses it will also be important to monitor social sustainability over time (for example, every two to three years). This also presupposes that reflexivity is embedded in the design process and that the housebuilders will use the results to reconfigure practice and design during the development process. Encouragingly, Acton Gardens LLP have made public commitments to respond to this research, highlighting four main areas they will act on: supporting residents in new housing to help them settle in the neighbourhood; ensuring that existing residents of the South Acton Estate fully understand the re-housing process; accommodating local organisations offering important support services to the community and recognising the value that residents place on their relationships with friends and neighbours in the area [38,39]. Efforts to improve information provision and engagement with residents (for example, in relation to phasing) has also increased, as a result of the research findings: for example, the community board is now larger and more diverse, and there are more resident forums and housing "surgeries" (to discuss housing issues with residents).

\section{CONCLUSIONS}

The framework used in this research is designed to help highlight broad comparisons with appropriate benchmarks for comparable places and other housing developments for a UK housebuilder [1]. The framework draws on previous research which highlighted the importance of both physical and non-physical factors in the assessment of social sustainability in a built environment context $[4,14,36]$. Although the case study is UK-based it also carries resonance at an international level in the context of the restructuring of large housing estates, especially in Europe [30], and for the development of other conceptual frameworks for social sustainability in housing in other countries [5,7,13-15,19,20]. The assessment framework used, however, is an ex post ("downstream") measure for new housing and its social sustainability impacts, and so it should be distinguished from other academic research in the field, and ex ante ("upstream") assessment frameworks (such as BREEAM Communities) [13,21].

The framework also lends itself to further tracking of the estate regeneration periodically over time, for example, every two to three years, and there is evidence that the housebuilders have acted on the results to reconfigure practices during the development process. The framework also offers the potential for housebuilders and local authorities to engage with residents directly in assessing social sustainability in a comparative and measurable way as the estate regeneration continues over its lifecycle. 
However, as this is an initial study, it is early to say whether the estate regeneration of South Acton is a "success" yet, and the research shows that the feelings about the estate regeneration are, so far, "mixed". Although some residents talk about the positive nature of the regeneration and highlight the resilience of the community and quality of life, there is also a range of negative comments relating to potential displacement which will require further analysis in future research on the estate $[13,20,32,34]$.

In conclusion, this research is a cross-sectional study at one particular point in the estate regeneration lifecycle. To examine performance over time, further research will be required to track the new and existing residents longitudinally and to analyse displacement in detail. In short, social sustainability, in contrast to the other pillars of sustainable development, remains a relatively new concept in the UK in relation to housing, and more specifically "estate regeneration". It demands fresh evidence, new language and new tools to understand this crucial area of sustainability and the continuing implications of the UK government's focus on "estate regeneration".

\section{FUNDING}

The research on which this paper is based was commissioned by Acton Gardens LLP, a partnership between L \& Q, Ealing Council and Countryside Properties. The data was collected and analysed by the authors in an independent research project. The views expressed in the paper are also the authors' own. There is no conflict of interest. The funders of the research had no role in the data collection and analysis, decision to publish or preparation of the manuscript.

\section{AUTHOR CONTRIBUTIONS}

NB, LCA, TD and EN designed the study, carried out the research, and analysed the data. The statistical analysis was carried out by AN. TD and NB wrote the paper with input from all authors.

\section{CONFLICTS OF INTEREST}

The authors declare no conflicts of interest.

\section{ACKNOWLEDGMENTS}

The authors would like to thank all the interviewees who contributed to the study and Acton Gardens LLP for commissioning the research. They would also like to thank the editors and the reviewers of this paper for their helpful comments. 


\section{Technical Appendices}

\section{APPENDIX A1. INDICATORS USED IN THE SOCIAL SUSTAINABILITY FRAMEWORK}

\section{Social and Cultural Life}

\begin{tabular}{|c|c|c|c|}
\hline Local identity & Code & Question & National survey \\
\hline $\begin{array}{l}\text { Positive local identity } \\
\text { (SC1) }\end{array}$ & SC_1a & $\begin{array}{l}\text { I plan to remain a resident of this neighbourhood for a } \\
\text { number of years. }\end{array}$ & $\begin{array}{l}\text { Understanding } \\
\text { Society survey }\end{array}$ \\
\hline $\begin{array}{l}\text { Positive local identity } \\
\text { (SC1) }\end{array}$ & SC_1b & $\begin{array}{l}\text { I feel like I belong to this neighbourhood, by this I } \\
\text { mean 15-20 minute walk from your home? }\end{array}$ & $\begin{array}{l}\text { Understanding } \\
\text { Society survey }\end{array}$ \\
\hline $\begin{array}{l}\text { Positive local identity } \\
\text { (SC1) }\end{array}$ & SC_1c & $\begin{array}{l}\text { How important is where you live to your sense of who } \\
\text { you are? }\end{array}$ & $\begin{array}{l}\text { Understanding } \\
\text { Society survey }\end{array}$ \\
\hline \multicolumn{4}{|l|}{ Links with neighbours } \\
\hline $\begin{array}{l}\text { Relationships with } \\
\text { neighbours (SC2) }\end{array}$ & SC_2a & $\begin{array}{l}\text { If I needed advice about something I could go to } \\
\text { someone in my neighbourhood. }\end{array}$ & $\begin{array}{l}\text { Understanding } \\
\text { Society survey }\end{array}$ \\
\hline $\begin{array}{l}\text { Relationships with } \\
\text { neighbours (SC2) }\end{array}$ & $\mathrm{SC} \_2 \mathrm{~b}$ & $\begin{array}{l}\text { I borrow things and exchange favours with my } \\
\text { neighbours. }\end{array}$ & $\begin{array}{l}\text { Understanding } \\
\text { Society survey }\end{array}$ \\
\hline $\begin{array}{l}\text { Relationships with } \\
\text { neighbours (SC2) }\end{array}$ & SC_2C & $\begin{array}{l}\text { I regularly stop and talk with people in my } \\
\text { neighbourhood. }\end{array}$ & $\begin{array}{l}\text { Understanding } \\
\text { Society survey }\end{array}$ \\
\hline $\begin{array}{l}\text { Relationships with } \\
\text { neighbours (SC2) }\end{array}$ & SC_2d & $\begin{array}{l}\text { The friendships and associations I have with other } \\
\text { people in my neighbourhood mean a lot to me. }\end{array}$ & $\begin{array}{l}\text { Citizenship } \\
\text { survey }\end{array}$ \\
\hline $\begin{array}{l}\text { Relationships with } \\
\text { neighbours (SC2) }\end{array}$ & SC_2e & $\begin{array}{l}\text { To what extent do you agree or disagree that this local } \\
\text { area is a place where people from different } \\
\text { backgrounds get on well together? }\end{array}$ & $\begin{array}{l}\text { Citizenship } \\
\text { survey }\end{array}$ \\
\hline $\begin{array}{l}\text { Relationships with } \\
\text { neighbours (SC2) }\end{array}$ & SC_2f & $\begin{array}{l}\text { Generally speaking would you say that most people } \\
\text { can be trusted, or that you can't be too careful in } \\
\text { dealing with people? }\end{array}$ & $\begin{array}{l}\text { Understanding } \\
\text { Society survey }\end{array}$ \\
\hline $\begin{array}{l}\text { Relationships with } \\
\text { neighbours (SC2) }\end{array}$ & SC_2g & $\begin{array}{l}\text { Residents in this local area respect ethnic differences } \\
\text { between people }\end{array}$ & $\begin{array}{l}\text { Understanding } \\
\text { Society survey }\end{array}$ \\
\hline \multicolumn{4}{|l|}{ Wellbeing } \\
\hline Wellbeing (SC3) & SC_3a & Recently I have been feeling reasonably happy. & $\begin{array}{l}\text { Understanding } \\
\text { Society survey }\end{array}$ \\
\hline Well-being (SC3) & $\mathrm{SC} 33 \mathrm{~b}$ & $\begin{array}{l}\text { Have you recently felt like you were playing a useful } \\
\text { part in things? }\end{array}$ & $\begin{array}{l}\text { Understanding } \\
\text { Society survey }\end{array}$ \\
\hline Well-being (SC3) & $\mathrm{SC} 33 \mathrm{C}$ & $\begin{array}{l}\text { Overall, how satisfied or dissatisfied are you with your } \\
\text { local area as a place to live? }\end{array}$ & $\begin{array}{l}\text { Citizenship } \\
\text { survey }\end{array}$ \\
\hline Well-being (SC3) & SC_3d & Satisfaction with life overall. & $\begin{array}{l}\text { Understanding } \\
\text { Society survey }\end{array}$ \\
\hline \multicolumn{4}{|l|}{ Feelings of safety } \\
\hline Feelings of safety (SC4) & $\mathrm{SC}_{-} 4 \mathrm{a}$ & $\begin{array}{l}\text { How safe do you feel walking alone in this area after } \\
\text { dark? }\end{array}$ & $\begin{array}{l}\text { Crime Survey for } \\
\text { England \& Wales }\end{array}$ \\
\hline Feelings of safety (SC4) & $\mathrm{SC}_{-} 4 \mathrm{~b}$ & $\begin{array}{l}\text { How safe do you feel walking alone in this area during } \\
\text { the day? }\end{array}$ & $\begin{array}{l}\text { Crime Survey for } \\
\text { England \& Wales }\end{array}$ \\
\hline Feelings of safety (SC4) & $\mathrm{SC}_{-} 4 \mathrm{C}$ & $\begin{array}{l}\text { Compared to the country as a whole what do you think } \\
\text { the level of crime in your local area is? }\end{array}$ & $\begin{array}{l}\text { Crime Survey for } \\
\text { England \& Wales }\end{array}$ \\
\hline
\end{tabular}


Voice and Influence

\begin{tabular}{|c|c|c|c|}
\hline Willingness to act & Code & Question & National survey \\
\hline $\begin{array}{l}\text { Willingness to act to } \\
\text { improve area (VI2) }\end{array}$ & VI_2a & $\begin{array}{l}\text { I would be willing to work together with others on } \\
\text { something to improve my neighbourhood. }\end{array}$ & $\begin{array}{l}\text { Understanding } \\
\text { Society survey }\end{array}$ \\
\hline $\begin{array}{l}\text { Willingness to act to } \\
\text { improve area (VI2) }\end{array}$ & VI_2b & $\begin{array}{l}\text { In the last } 12 \text { months, have you taken any of the } \\
\text { following actions to try to get something done about } \\
\text { the quality of your local environment? }\end{array}$ & $\begin{array}{l}\text { Taking Part } \\
\text { survey }\end{array}$ \\
\hline $\begin{array}{l}\text { Willingness to act to } \\
\text { improve area (VI2) }\end{array}$ & VI_2c & $\begin{array}{l}\text { Have you taken part in any of these groups? } \\
\text { (aggregate) (e.g., religious, community, sport etc) }\end{array}$ & $\begin{array}{l}\text { Taking Part } \\
\text { survey }\end{array}$ \\
\hline $\begin{array}{l}\text { Willingness to act to } \\
\text { improve area (VI2) }\end{array}$ & VI_2d & $\begin{array}{l}\text { To what extent do you agree or disagree that people in } \\
\text { this neighbourhood pull together to improve this } \\
\text { neighbourhood? }\end{array}$ & $\begin{array}{l}\text { Citizenship } \\
\text { survey }\end{array}$ \\
\hline $\begin{array}{l}\text { Willingness to act to } \\
\text { improve area (VI2) }\end{array}$ & VI_2d & $\begin{array}{l}\text { During the past } 12 \text { months have you done any } \\
\text { voluntary work? }\end{array}$ & $\begin{array}{l}\text { Taking Part } \\
\text { survey }\end{array}$ \\
\hline \multicolumn{4}{|l|}{ Ability to influence } \\
\hline $\begin{array}{l}\text { Perceptions of ability to } \\
\text { influence local area (VI1) }\end{array}$ & VI_1a & $\begin{array}{l}\text { In the last } 12 \text { months, has any organisation asked you } \\
\text { what you do/think about? (sporting facilities, cultural } \\
\text { facilities, environmental facilities) }\end{array}$ & $\begin{array}{l}\text { Taking Part } \\
\text { survey }\end{array}$ \\
\hline $\begin{array}{l}\text { Perceptions of ability to } \\
\text { influence local area (VI1) }\end{array}$ & VI_1b & $\begin{array}{l}\text { Do you agree or disagree that you can influence } \\
\text { decisions affecting your local area? }\end{array}$ & $\begin{array}{l}\text { Citizenship } \\
\text { survey }\end{array}$ \\
\hline $\begin{array}{l}\text { Perceptions of ability to } \\
\text { influence local area (VI1) }\end{array}$ & VI_1c & $\begin{array}{l}\text { How important is it for you personally to feel that you } \\
\text { can influence decisions affecting your local area? }\end{array}$ & $\begin{array}{l}\text { Citizenship } \\
\text { survey }\end{array}$ \\
\hline
\end{tabular}

\section{Amenities and Infrastructure}

\begin{tabular}{|c|c|c|c|}
\hline Community space & Code & Question & Site survey \\
\hline $\begin{array}{l}\text { Provision of community } \\
\text { space (AI_1) }\end{array}$ & AI_1a & $\begin{array}{l}\text { Does the development provide (or is it close to) } \\
\text { community facilities, such as a school, parks, play } \\
\text { areas, shops, pubs or cafés? }\end{array}$ & Building for Life \\
\hline $\begin{array}{l}\text { Provision of community } \\
\text { space (AI1) }\end{array}$ & AI_1b & $\begin{array}{l}\text { Is public space well designed and does it have suitable } \\
\text { management arrangements in place? }\end{array}$ & Building for Life \\
\hline $\begin{array}{l}\text { Provision of community } \\
\text { space (AI_1) }\end{array}$ & AI_1c & $\begin{array}{l}\text { Have the community facilities been appropriately } \\
\text { provided? }\end{array}$ & Created question \\
\hline \multicolumn{4}{|l|}{ Transport links } \\
\hline Transport links & AI_2 & Public transport accessibility. & $\begin{array}{l}\text { PTAL plus site } \\
\text { specific } \\
\text { documents }\end{array}$ \\
\hline \multicolumn{4}{|l|}{ Distinctive character } \\
\hline $\begin{array}{l}\text { Place with a distinctive } \\
\text { character (AI_3) }\end{array}$ & AI_3a & $\begin{array}{l}\text { Does the scheme feel like a place with distinctive } \\
\text { character? }\end{array}$ & Building for Life \\
\hline \multicolumn{4}{|l|}{ Local integration } \\
\hline $\begin{array}{l}\text { Integration with wider } \\
\text { neighbourhood (AI4) }\end{array}$ & AI_4a & $\begin{array}{l}\text { Is there an accommodation mix that reflects the needs } \\
\text { and aspirations of the local community? }\end{array}$ & Building for Life \\
\hline $\begin{array}{l}\text { Integration with wider } \\
\text { neighbourhood (AI_4) }\end{array}$ & AI_4b & $\begin{array}{l}\text { Is there a tenure mix that reflects the needs of the local } \\
\text { community? }\end{array}$ & Building for Life \\
\hline
\end{tabular}




\begin{tabular}{|c|c|c|c|}
\hline $\begin{array}{l}\text { Integration with wider } \\
\text { neighbourhood (AI_4) }\end{array}$ & AI_4c & $\begin{array}{l}\text { Does the design of the local environment promote } \\
\text { engagement with the wider community? }\end{array}$ & Created question \\
\hline \multicolumn{4}{|l|}{ Street layout } \\
\hline $\begin{array}{l}\text { Accessible and safe street } \\
\text { layout (AI_5) }\end{array}$ & AI_5a & $\begin{array}{l}\text { Do the buildings and layout make it easy to find your } \\
\text { way around? }\end{array}$ & Building for Life \\
\hline $\begin{array}{l}\text { Accessible and safe street } \\
\text { layout (AI_5) }\end{array}$ & AI_5b & $\begin{array}{l}\text { Does the scheme integrate with existing streets, paths } \\
\text { and surrounding development? }\end{array}$ & Building for Life \\
\hline $\begin{array}{l}\text { Accessible and safe street } \\
\text { layout (AI_5) }\end{array}$ & AI_5c & Are the streets pedestrian, cycle and vehicle friendly? & Building for Life \\
\hline $\begin{array}{l}\text { Accessible and safe street } \\
\text { layout (AI5) }\end{array}$ & AI_5d & $\begin{array}{l}\text { Are public spaces and pedestrian routes overlooked } \\
\text { and do they feel safe? }\end{array}$ & Building for Life \\
\hline $\begin{array}{l}\text { Accessible street layout } \\
\text { (AI_5) }\end{array}$ & AI_5e & $\begin{array}{l}\text { Does the design of the local environment adequately } \\
\text { support the needs of people with limited physical } \\
\text { mobility? }\end{array}$ & Created question \\
\hline \multicolumn{4}{|l|}{ Adaptable space } \\
\hline $\begin{array}{l}\text { Physical space on } \\
\text { development that is } \\
\text { adaptable in the future } \\
\text { (AI_6) }\end{array}$ & AI_6a & $\begin{array}{l}\text { Do internal spaces and layout allow for adaption, } \\
\text { conversion or extension? }\end{array}$ & Building for Life \\
\hline $\begin{array}{l}\text { Physical space on } \\
\text { development that is } \\
\text { adaptable in the future } \\
\text { (AI6) }\end{array}$ & AI_6b & $\begin{array}{l}\text { Do external spaces and layout allow for adaption, } \\
\text { conversion or extension? }\end{array}$ & Created question \\
\hline
\end{tabular}


APPENDIX A2. SCORING BY DATA SOURCE

\begin{tabular}{|c|c|}
\hline Data source & Scoring approach \\
\hline $\begin{array}{l}\text { Residents' survey: } \\
\text { questions taken } \\
\text { from national } \\
\text { surveys }\end{array}$ & $\begin{array}{l}\text { Questions benchmarked against national comparable places (OAC and IMD) using z-score } \\
\text { approach. } \\
\text { The z-score for each question within an indicator provided the overall score for each indicator. } \\
\text { The overall score was rated: } \\
\text { - Statistically significant responses above the benchmark = green } \\
\text { - Responses are the same as or similar to the benchmark, or they are not statistically } \\
\text { significant = blue } \\
\text { - Statistically significant responses below the benchmark = orange }\end{array}$ \\
\hline $\begin{array}{l}\text { Site survey: } \\
\text { questions taken } \\
\text { from Building for } \\
\text { Life }\end{array}$ & $\begin{array}{l}\text { The Building for Life scoring protocol was used. Each of the questions is given a value of } 1,0.5 \\
\text { or } 0 . \\
\text { - } 1 \text { = there is sufficient evidence that the design meets the criteria } \\
\text { - } 0.5 \text { = a specific part of the design meets the criteria, but another does not } \\
\text { - } 0 \text { = there is not enough evidence that the design meets the criteria, or the evidence } \\
\text { shows that the design does not meet the criteria. } \\
\text { The mean of the scores for each question within an indicator were combined to provide an } \\
\text { overall mean score for each indicator. } \\
\text { This overall mean score was rated: } \\
\text { - } \quad \geq 0.75 \text { = green } \\
\text { - } \geq 0.5 \text { but }<0.75=\text { blue } \\
\text { - }<0.5=\text { orange }\end{array}$ \\
\hline $\begin{array}{l}\text { Site survey: } \\
\text { questions created } \\
\text { for the project }\end{array}$ & Questions were scored in the same way as those taken from Building for Life \\
\hline $\begin{array}{l}\text { Public Transport } \\
\text { Accessibility Level } \\
\text { (PTAL) }\end{array}$ & $\begin{array}{l}\text { PTAL scores are graded between } 1 \text { (extremely poor access to public transport) and } 6 \text { (excellent } \\
\text { access to public transport). } \\
\text { The PTAL scores were rated: } \\
\begin{array}{l}\text { - } \quad \geq 5 \text { = green } \\
\text { - } \geq 3 \text { but }<5 \text { = blue } \\
\text { - } \quad<3 \text { = orange }\end{array}\end{array}$ \\
\hline
\end{tabular}




\section{APPENDIX A3. BENCHMARKS ACTON GARDENS AND SOUTH ACTON (EXCLUDING AMENITIES AND INFRASTRUCTURE (SCORED IN SEPARATE SITE SURVEY))}

\section{SCORES}

- -1 = STATISTICALLY WORSE THAN COMPARABLE AREAS (Statistically significant responses below the benchmark = orange)

- 0 = AS EXPECTED (Responses are the same as or similar to the benchmark, or they are not statistically significant $=$ blue)

- 1= STATISTICALLY BETTER THAN COMPARABLE AREAS (Statistically significant responses above the benchmark = green)

Overall scores in each indicator set are based on the number of significantly different responses for each indicator. For example, if there are three or more green cells then the overall score is green ( $=1$ score overall). If there are one or fewer green cells, then this is scored as a zero (blue), unless there is more than one orange cell, in which case it is scored overall as -1 . As can be seen, all overall scores are either 1 (green) or zero (blue) for the criteria shown.

\begin{tabular}{|c|c|c|c|c|c|}
\hline \multicolumn{4}{|c|}{ Social and Cultural CRITERIA: LOCAL IDENTITY } & \multirow[b]{2}{*}{ z score } & \multirow{2}{*}{$\begin{array}{c}\text { SCORE } \\
0\end{array}$} \\
\hline $\begin{array}{l}\text { Acton Gardens phase one/ } \\
\text { national benchmarks }\end{array}$ & $\begin{array}{l}\text { Acton } \\
\text { Gardens }\end{array}$ & $\begin{array}{l}\text { Comparable } \\
\text { area }\end{array}$ & $\begin{array}{l}\text { Difference to } \\
\text { comparable area }\end{array}$ & & \\
\hline $\begin{array}{l}\text { Plan to remain resident of this } \\
\text { neighbourhood for a number of } \\
\text { years }\end{array}$ & $80.5 \%$ & $51.4 \%$ & $29.1 \%$ & 3.69 & \\
\hline $\begin{array}{l}\text { Feel like I belong to this } \\
\text { neighbourhood }\end{array}$ & $61.0 \%$ & $58.1 \%$ & $2.9 \%$ & 0.37 & \\
\hline $\begin{array}{l}\text { Importance of where you live to } \\
\text { sense of who you are }\end{array}$ & $90.2 \%$ & $72.1 \%$ & $18.1 \%$ & 2.58 & \\
\hline $\begin{array}{l}\text { South Acton estate/national } \\
\text { benchmarks }\end{array}$ & $\begin{array}{l}\text { South } \\
\text { Acton }\end{array}$ & $\begin{array}{l}\text { Comparable } \\
\text { area }\end{array}$ & $\begin{array}{l}\text { Difference to } \\
\text { comparable area }\end{array}$ & z score & 1 \\
\hline $\begin{array}{l}\text { Plan to remain resident of this } \\
\text { neighbourhood for a number of } \\
\text { years }\end{array}$ & $84.6 \%$ & $51.4 \%$ & $33.2 \%$ & 9.85 & \\
\hline $\begin{array}{l}\text { Feel like I belong to this } \\
\text { neighbourhood }\end{array}$ & $86.2 \%$ & $58.1 \%$ & $28.1 \%$ & 8.52 & \\
\hline $\begin{array}{l}\text { Importance of where you live to } \\
\text { sense of who you are }\end{array}$ & $94.4 \%$ & $72.1 \%$ & $22.3 \%$ & 7.50 & \\
\hline \multicolumn{5}{|c|}{ Social and Cultural CRITERIA: LINKS WITH NEIGHBOURS } & SCORE \\
\hline $\begin{array}{l}\text { Acton Gardens phase one/ } \\
\text { national benchmarks }\end{array}$ & $\begin{array}{l}\text { Acton } \\
\text { Gardens }\end{array}$ & $\begin{array}{l}\text { Comparable } \\
\text { area }\end{array}$ & $\begin{array}{l}\text { Difference to } \\
\text { comparable area }\end{array}$ & z score & 0 \\
\hline $\begin{array}{l}\text { If I needed advice I could go to } \\
\text { someone in my neighbourhood }\end{array}$ & $51.2 \%$ & $42.9 \%$ & $8.3 \%$ & 1.07 & \\
\hline $\begin{array}{l}\text { I borrow things and exchange } \\
\text { favours with my neighbours }\end{array}$ & $43.9 \%$ & $33.7 \%$ & $10.2 \%$ & 1.36 & \\
\hline $\begin{array}{l}\text { I regularly stop and talk with } \\
\text { people in my neighbourhood }\end{array}$ & $43.9 \%$ & $55.8 \%$ & $-11.9 \%$ & -1.52 & \\
\hline
\end{tabular}




\begin{tabular}{|c|c|c|c|c|c|}
\hline $\begin{array}{l}\text { Acton Gardens phase one/ } \\
\text { national benchmarks }\end{array}$ & $\begin{array}{l}\text { Acton } \\
\text { Gardens }\end{array}$ & $\begin{array}{l}\text { Comparable } \\
\text { area }\end{array}$ & $\begin{array}{l}\text { Difference to } \\
\text { comparable area }\end{array}$ & z score & 0 \\
\hline $\begin{array}{l}\text { Friendships in my neighbourhood } \\
\text { mean a lot to me }\end{array}$ & $51.2 \%$ & $50.8 \%$ & $0.4 \%$ & 0.05 & \\
\hline $\begin{array}{l}\text { Most people can be trusted or you } \\
\text { cannot be too careful with people }\end{array}$ & $39.0 \%$ & $38.2 \%$ & $0.8 \%$ & 0.10 & \\
\hline $\begin{array}{l}\text { People from different backgrounds } \\
\text { get on well }\end{array}$ & $84.8 \%$ & $80.9 \%$ & $4.0 \%$ & 0.56 & \\
\hline $\begin{array}{l}\text { Residents in this local area respect } \\
\text { ethnic differences between people }\end{array}$ & $88.6 \%$ & $87.2 \%$ & $1.4 \%$ & 0.23 & \\
\hline $\begin{array}{l}\text { South Acton estate/national } \\
\text { benchmarks }\end{array}$ & South Acton & $\begin{array}{l}\text { Comparable } \\
\text { area }\end{array}$ & $\begin{array}{l}\text { Difference to } \\
\text { comparable area }\end{array}$ & z score & 1 \\
\hline $\begin{array}{l}\text { If I needed advice I could go to } \\
\text { someone in my neighbourhood }\end{array}$ & $80.2 \%$ & $42.9 \%$ & $37.3 \%$ & 11.04 & \\
\hline $\begin{array}{l}\text { I borrow things and exchange } \\
\text { favours with my neighbours }\end{array}$ & $41.8 \%$ & $33.7 \%$ & $8.0 \%$ & 2.50 & \\
\hline $\begin{array}{l}\text { I regularly stop and talk with } \\
\text { people in my neighbourhood }\end{array}$ & $76.4 \%$ & $55.8 \%$ & $20.6 \%$ & 6.21 & \\
\hline $\begin{array}{l}\text { Friendships in my neighbourhood } \\
\text { mean a lot to me }\end{array}$ & $81.3 \%$ & $50.8 \%$ & $30.5 \%$ & 9.04 & \\
\hline $\begin{array}{l}\text { Most people can be trusted or you } \\
\text { cannot be too careful with people }\end{array}$ & $12.3 \%$ & $38.2 \%$ & $-25.9 \%$ & -6.63 & \\
\hline $\begin{array}{l}\text { People from different backgrounds } \\
\text { get on well }\end{array}$ & $90.0 \%$ & $80.9 \%$ & $9.1 \%$ & 2.94 & \\
\hline $\begin{array}{l}\text { Residents in this local area respect } \\
\text { ethnic differences between people }\end{array}$ & $92.0 \%$ & $87.2 \%$ & $4.8 \%$ & 1.63 & \\
\hline \multicolumn{3}{|c|}{ Social \& Cultural CRITERIA: WELLBEING } & & & SCORE \\
\hline $\begin{array}{l}\text { Acton Gardens phase one/ } \\
\text { national benchmarks }\end{array}$ & $\begin{array}{l}\text { Acton } \\
\text { Gardens }\end{array}$ & $\begin{array}{l}\text { Comparable } \\
\text { area }\end{array}$ & $\begin{array}{l}\text { Difference to } \\
\text { comparable area }\end{array}$ & z score & 1 \\
\hline $\begin{array}{l}\text { Have you recently felt that you } \\
\text { were playing a useful part in } \\
\text { things? }\end{array}$ & $92.5 \%$ & $81.1 \%$ & $11.4 \%$ & 1.83 & \\
\hline $\begin{array}{l}\text { Have you been feeling reasonably } \\
\text { happy? }\end{array}$ & $95.1 \%$ & $83.6 \%$ & $11.5 \%$ & 1.98 & \\
\hline $\begin{array}{l}\text { How dissatisfied or satisfied are } \\
\text { you with life overall? }\end{array}$ & $92.7 \%$ & $65.1 \%$ & $27.5 \%$ & 3.68 & \\
\hline $\begin{array}{l}\text { Overall, how satisfied or } \\
\text { dissatisfied are you with your local } \\
\text { area as a place to live? }\end{array}$ & $90.2 \%$ & $76.5 \%$ & $13.8 \%$ & 2.01 & \\
\hline
\end{tabular}




\begin{tabular}{|c|c|c|c|c|c|}
\hline $\begin{array}{l}\text { South Acton estate/national } \\
\text { benchmarks }\end{array}$ & South Acton & $\begin{array}{l}\text { Comparable } \\
\text { area }\end{array}$ & $\begin{array}{l}\text { Difference to } \\
\text { comparable area }\end{array}$ & z score & 1 \\
\hline $\begin{array}{l}\text { Have you recently felt that you } \\
\text { were playing a useful part in } \\
\text { things? }\end{array}$ & $86.3 \%$ & $81.1 \%$ & $5.2 \%$ & 1.93 & \\
\hline $\begin{array}{l}\text { Have you been feeling reasonably } \\
\text { happy? }\end{array}$ & $89.0 \%$ & $83.6 \%$ & $5.4 \%$ & 2.17 & \\
\hline $\begin{array}{l}\text { How dissatisfied or satisfied are } \\
\text { you with life overall? }\end{array}$ & $86.3 \%$ & $65.1 \%$ & $21.2 \%$ & 6.61 & \\
\hline $\begin{array}{l}\text { Overall, how satisfied or } \\
\text { dissatisfied are you with your local } \\
\text { area as a place to live? }\end{array}$ & $88.1 \%$ & $76.5 \%$ & $11.6 \%$ & 3.40 & \\
\hline \multicolumn{4}{|c|}{ Social and Cultural CRITERIA: FEELINGS OF SAFETY } & & SCORE \\
\hline $\begin{array}{l}\text { Acton Gardens phase one/ } \\
\text { national benchmarks }\end{array}$ & $\begin{array}{l}\text { Acton } \\
\text { Gardens }\end{array}$ & $\begin{array}{l}\text { Comparable } \\
\text { area }\end{array}$ & $\begin{array}{l}\text { Difference to } \\
\text { comparable area }\end{array}$ & z score & 0 \\
\hline $\begin{array}{l}\text { How safe do you feel walking } \\
\text { alone in this area during the day? }\end{array}$ & $100.0 \%$ & $95.5 \%$ & $4.5 \%$ & 1.38 & \\
\hline $\begin{array}{l}\text { How safe do you feel walking } \\
\text { alone in this area after dark? }\end{array}$ & $95.1 \%$ & $63.7 \%$ & $31.4 \%$ & 4.18 & \\
\hline $\begin{array}{l}\text { Compared to the country as a } \\
\text { whole do you think the level of } \\
\text { crime in your local area is... }\end{array}$ & $45.5 \%$ & $51.7 \%$ & $-6.2 \%$ & -0.72 & \\
\hline $\begin{array}{l}\text { South Acton estate/ } \\
\text { national benchmarks }\end{array}$ & South Acton & $\begin{array}{l}\text { Comparable } \\
\text { area }\end{array}$ & $\begin{array}{l}\text { Difference to } \\
\text { comparable area }\end{array}$ & z score & 0 \\
\hline $\begin{array}{l}\text { How safe do you feel walking } \\
\text { alone in this area during the day? }\end{array}$ & $96.8 \%$ & $95.5 \%$ & $1.3 \%$ & 0.96 & \\
\hline $\begin{array}{l}\text { How safe do you feel walking } \\
\text { alone in this area after dark? }\end{array}$ & $80.6 \%$ & $63.7 \%$ & $16.9 \%$ & 4.93 & \\
\hline $\begin{array}{l}\text { Compared to the country as a } \\
\text { whole do you think the level of } \\
\text { crime in your local area is... }\end{array}$ & $42.1 \%$ & $51.7 \%$ & $-9.6 \%$ & -2.48 & \\
\hline \multicolumn{4}{|c|}{ Voice and Influence CRITERIA: WILLINGNESS TO ACT } & & SCORE \\
\hline $\begin{array}{l}\text { Acton Gardens phase one/ } \\
\text { national benchmarks }\end{array}$ & $\begin{array}{l}\text { Acton } \\
\text { Gardens }\end{array}$ & $\begin{array}{l}\text { Comparable } \\
\text { area }\end{array}$ & $\begin{array}{l}\text { Difference to } \\
\text { comparable area }\end{array}$ & z score & 0 \\
\hline $\begin{array}{l}\text { I would be willing to work together } \\
\text { with others on something to } \\
\text { improve my neighbourhood. }\end{array}$ & $65.9 \%$ & $70.2 \%$ & $-4.4 \%$ & -0.60 & \\
\hline $\begin{array}{l}\text { In the last } 12 \text { months, have you } \\
\text { taken any of the actions on this } \\
\text { card to try to get something done } \\
\text { about the quality of your local } \\
\text { environment? (aggregate) }\end{array}$ & $2.8 \%$ & $4.0 \%$ & $-1.2 \%$ & 1.30 & \\
\hline $\begin{array}{l}\text { Have you taken part in any of } \\
\text { these groups? (aggregate) }\end{array}$ & $6.8 \%$ & $10.1 \%$ & $-3.3 \%$ & -0.38 & \\
\hline
\end{tabular}




\begin{tabular}{|c|c|c|c|c|c|}
\hline $\begin{array}{l}\text { Acton Gardens phase one/ } \\
\text { national benchmarks }\end{array}$ & $\begin{array}{l}\text { Acton } \\
\text { Gardens }\end{array}$ & $\begin{array}{l}\text { Comparable } \\
\text { area }\end{array}$ & $\begin{array}{l}\text { Difference to } \\
\text { comparable area }\end{array}$ & z score & 0 \\
\hline $\begin{array}{l}\text { People in this neighbourhood pull } \\
\text { together to improve the } \\
\text { neighbourhood }\end{array}$ & $77.8 \%$ & $54.3 \%$ & $23.5 \%$ & 2.36 & \\
\hline $\begin{array}{l}\text { During the last } 12 \text { months, have } \\
\text { you done any voluntary work? }\end{array}$ & $10.0 \%$ & $18.1 \%$ & $-8.1 \%$ & -1.32 & \\
\hline $\begin{array}{l}\text { South Acton estate/ } \\
\text { national benchmarks }\end{array}$ & South Acton & $\begin{array}{l}\text { Comparable } \\
\text { area }\end{array}$ & $\begin{array}{l}\text { Difference to } \\
\text { comparable area }\end{array}$ & z score & 0 \\
\hline $\begin{array}{l}\text { I would be willing to work together } \\
\text { with others on something to } \\
\text { improve my neighbourhood. }\end{array}$ & $84.2 \%$ & $70.2 \%$ & $14.0 \%$ & 4.60 & \\
\hline $\begin{array}{l}\text { In the last } 12 \text { months, have you } \\
\text { taken any of the actions on this } \\
\text { card to try to get something done } \\
\text { about the quality of your local } \\
\text { environment? (aggregate) }\end{array}$ & $7.1 \%$ & $3.9 \%$ & $3.2 \%$ & 1.67 & \\
\hline $\begin{array}{l}\text { Have you taken part in any of } \\
\text { these groups? (aggregate) }\end{array}$ & $6.5 \%$ & $10.1 \%$ & $-3.6 \%$ & -1.62 & \\
\hline $\begin{array}{l}\text { People in this neighbourhood pull } \\
\text { together to improve the } \\
\text { neighbourhood }\end{array}$ & $82.8 \%$ & $54.3 \%$ & $28.6 \%$ & 6.62 & \\
\hline $\begin{array}{l}\text { During the last } 12 \text { months, have } \\
\text { you done any voluntary work? }\end{array}$ & $10.4 \%$ & $18.1 \%$ & $-7.7 \%$ & -3.04 & \\
\hline \multicolumn{2}{|c|}{$\begin{array}{l}\text { Voice and Influence CRITERIA: ABILITY TO } \\
\text { INFLUENCE }\end{array}$} & & & & SCORE \\
\hline $\begin{array}{l}\text { Acton Gardens phase one/ } \\
\text { national benchmarks }\end{array}$ & $\begin{array}{l}\text { Acton } \\
\text { Gardens }\end{array}$ & $\begin{array}{l}\text { Comparable } \\
\text { area }\end{array}$ & $\begin{array}{l}\text { Difference to } \\
\text { comparable area }\end{array}$ & z score & 0 \\
\hline $\begin{array}{l}\text { In the last } 12 \text { months, has any } \\
\text { organisation asked you what you } \\
\text { think about (sporting facilities, } \\
\text { cultural facilities, environmental } \\
\text { facilities) }\end{array}$ & $1.6 \%$ & $6.2 \%$ & $-4.6 \%$ & -0.19 & \\
\hline $\begin{array}{l}\text { Do you agree or disagree that you } \\
\text { can influence decisions affecting } \\
\text { your local area? }\end{array}$ & $30.3 \%$ & $40.1 \%$ & $-9.8 \%$ & 1.266 & \\
\hline $\begin{array}{l}\text { How important is it for you } \\
\text { personally to feel that you can } \\
\text { influence decisions affecting your } \\
\text { local area? }\end{array}$ & $86.8 \%$ & $72.7 \%$ & $14.1 \%$ & 1.29 & \\
\hline
\end{tabular}




\begin{tabular}{|l|c|c|c|c|}
\hline $\begin{array}{l}\text { Acton Gardens phase one/ } \\
\text { national benchmarks }\end{array}$ & South Acton & $\begin{array}{l}\text { Comparable } \\
\text { area }\end{array}$ & $\begin{array}{l}\text { Difference to } \\
\text { comparable area }\end{array}$ & z score \\
\hline $\begin{array}{l}\text { In the last 12 months, has any } \\
\text { organisation asked you what you } \\
\text { think about (sporting facilities, } \\
\text { cultural facilities, environmental } \\
\text { facilities) }\end{array}$ & $2.0 \%$ & $6.2 \%$ & $-4.2 \%$ & -2.5 \\
\hline $\begin{array}{l}\text { Do you agree or disagree that you } \\
\text { can influence decisions affecting } \\
\text { your local area? }\end{array}$ & $47.9 \%$ & $40.1 \%$ & $7.8 \%$ & 1.62 \\
\hline $\begin{array}{l}\text { How important is it for you } \\
\text { personally to feel that you can } \\
\text { influence decisions affecting your } \\
\text { local area? }\end{array}$ & $72.9 \%$ & $72.7 \%$ & $0.2 \%$ & 0.038 \\
\hline
\end{tabular}




\section{APPENDIX A4. ATTITUDES TOWARDS ESTATE REGENERATION SURVEY QUESTIONS}

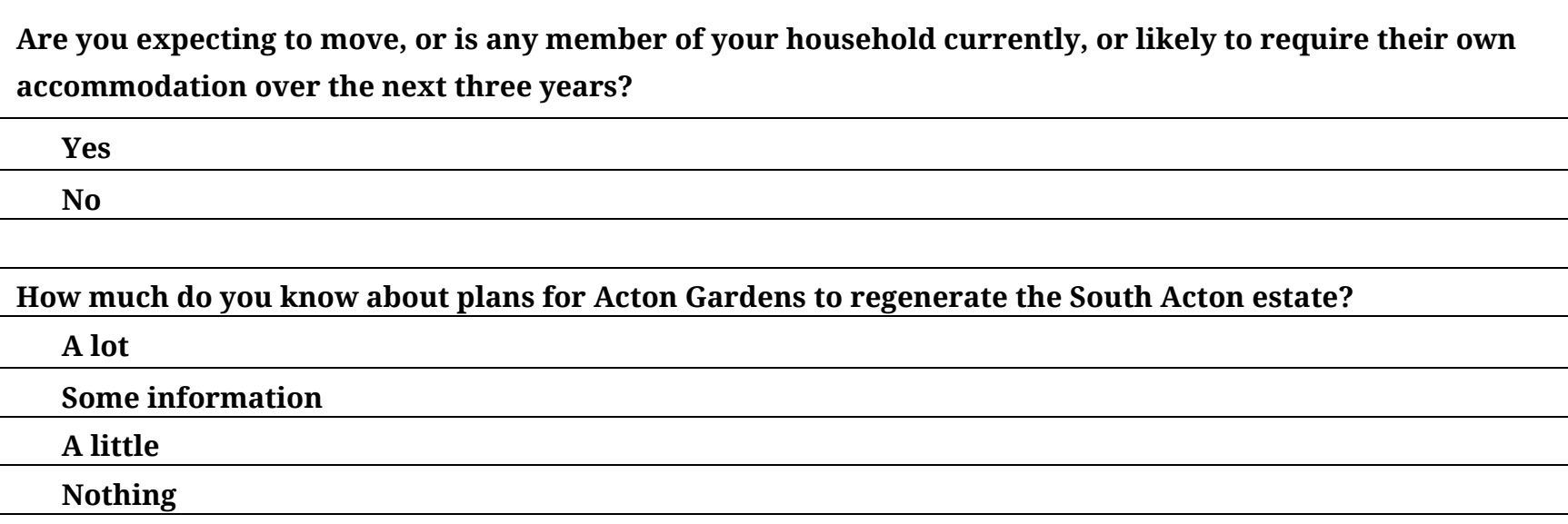

From what you know about the regeneration plans, what do you think about them?

How did you feel about the Acton Gardens regeneration project before you moved to your new home?

Can you tell me how you currently feel about the Acton Gardens regeneration project?

Overall, what three factors about living in this neighbourhood contribute most to your quality of life?

Have you attended any meetings or events to provide residents with information about the regeneration project in the past 12 months?

Yes

No

Have you received the Acton Gardens quarterly newsletter about the regeneration in the past 12 months?

Yes

No

Have you read this newsletter in the past 12 months?

Yes

No

How important is it for you personally to feel that you can influence decisions about the Acton Gardens regeneration project?

Very important

Quite important

Not very important

Not at all important 
What aspects of the regeneration project are most important to you?

Total number responding

Housing mix

Availability of new housing for South Acton residents

Improving housing quality

Improving quality of open spaces

Improving street layouts and lighting

Improving community safety

New community facilities

New health facilities

New facilities for young people

Affordability of housing

Disruption from building work

Other

Don't know

Other-specify

What do you think about the mix of new housing at Acton Gardens?

Very satisfied

satisfied

Neither satisfied nor dissatisfied

dissatisfied

Very dissatisfied

Which of the following facilities and services would you most like to see at Acton Gardens?

Total number responding

A youth club

Play areas

A Community centre

Local shops

Open space

Green space

Allotments

Cycle paths

Sports facilities

Outdoor gym

Public seating

Doctor's surgery

Dentist surgery

Nursery

Other

Don't know

other-specify 


\section{REFERENCES}

1. Bacon N, Cochrane D, Woodcraft S. Creating Strong Communities: How to Measure the Social Sustainability of New Housing Developments. London (UK): The Berkeley Group; 2012. Available from: https://www.berkeleygroup.co.uk/media/pdf/7/8/berkeley-reports-andopinions-social-sustainability-reports-creating-strong-communities-partone.pdf. Accessed 2019 Mar 1.

2. Woodcraft S. Reconfiguring the "social" in sustainable development: community, citizenship and innovation in new urban neighbourhoods. In: Murphy F, McDonagh P, editors. Envisioning Sustainabilities: Towards an Anthropology of Sustainability. Newcastle upon Tyne (UK): Cambridge Scholars Publishing; 2016.

3. HCA/JLL. Joining the Dots. Next Generation Benchmark Report. London (UK): Homes and Communities Agency/JLL; 2015.

4. Woodcraft S. Social sustainability and new communities: moving from concept to practice in the UK. Soc Behav Sci. 2012;68:30-42.

5. Shirazi MR, Keivani R. Critical reflections on the theory and practice of social sustainability in the built environment-a meta-analysis. Local Environ. 2017;22(12):1526-45.

6. Colantonio A. Social Sustainability: Linking Research to Policy and Practice. Oxford (UK): Oxford Institute for Sustainable Development, Oxford Brookes University; 2009.

7. Ancell S, Thompson M. The social sustainability of medium density housing: a conceptual model and Christchurch Case Study. Hous Stud. 2008;23(3): 423-42.

8. Colantonio A, Dixon T. Urban regeneration and social sustainability: Best practice from European cities. Chichester (UK): Wiley-Blackwell; 2011.

9. Woodcraft, S. Understanding and measuring social sustainability. J Urban Regen Renewal. 2015;8(2):133-44.

10. RSA. Developing Socially Productive Places. London (UK): Royal Society for the encouragement of Arts, Manufactures and Commerce; 2014. Available

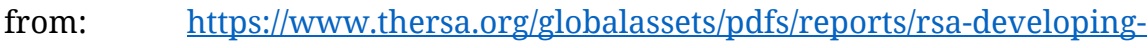
socially-productive-places.pdf. Accessed 2019 Mar 1.

11. Erdiaw-Kwasie MO, Basson M. Reimaging socio-spatial planning: towards a synthesis between sense of place and social sustainability approaches. Plan Theory. 2017;17(4):514-32.

12. Adams D, Payne S, Watkins C. Corporate social responsibility and the UK housebuilding industry. In Murray M, Dainty A, editors. Corporate Social Responsibility in the Construction Industry. London (UK): Taylor and Francis; 2008. p. 235-58.

13. Dixon T. Measuring the social sustainability of new housing development: a critical review of assessment methods. J Sustain Real Estate. Forthcoming 2019.

14. Dempsey N, Bramley G, Power S, Brown C. The Social Dimension of Sustainable Development: Defining Urban Social Sustainability. Sustain Dev. 2011;19(5):289-300. 
15. Chiu RLH. Social Sustainability, Sustainable Development and Housing Development: the Experience of Hong Kong. In Forrest R, Lee J, editors. Housing and Social Change: East-West Perspectives. London (UK): Routledge; 2003.

16. Magee L, Scerri A, James P. Measuring Social Sustainability: A CommunityCentred Approach. Appl Res Quality Life. 2012;7(3):239-61.

17. Cuthill, M. The contribution of human and social capital to building community well-being: A research agenda relating to citizen participation in local governance in Australia. Urban Policy Res. 2003;21(4):373-91.

18. Weingaertner C, Moberg A. Exploring Social Sustainability: Learning from Perspectives on Urban Development and Companies and Products. Sustain Dev. 2014;22(2):122-33.

19. Cuthill, M. The contribution of human and social capital to building community well-being: A research agenda relating to citizen participation in local governance in Australia. Urban Policy Res. 2003;21(4):373-91.

20. Stender M, Walter A. The role of social sustainability in building assessment. Build Res Inform. 2018;47(5):598-610. doi: 10.1080/09613218.2018.1468057

21. Callway RF, Dixon T, Nikolic D. Embedding green infrastructure evaluation in neighbourhood masterplans-does BREEAM Communities change anything? J Env Plan Manage. 2019. doi: 10.1080/09640568.2018.1563371

22. Hall S. Entre état et marche: Une brève histoire de la régénération urbaine en Angleterre [Between state and market: A brief history of urban regeneration in England]. In: Kirszbaum T, editor. En finir avec les banlieues? Le désenchantement de la politique de la ville. Paris (France): Les Editions de l'aube; 2015. p. 117-29. French.

23. Pattison B, Tyler P, Wells P, Wilson I. Regeneration Revival? Making housing-led regeneration work across England. Sheffield (UK): Charted Institute of Housing; 2016.

24. Mayor of London. Homes for Londoners: Draft Good Practice Guide to Estate Regeneration. London (UK): Greater London Authority; 2016.

25. DCLG. Estate Regeneration: Good Practice Guide (parts 1, 2 and 3). London (UK): DCLG; 2016. Available from: https://www.gov.uk/guidance/estateregeneration-national-strategy. Accessed 2019 Mar 1.

26. Mayor of London. Better Homes for Better People: The Mayor's Good Practice Guide to Estate Regeneration. London (UK): Greater London Authority (GLA); 2018.

27. DCLG. Estate Regeneration National Strategy. London (UK): DCLG; 2016. Available from: https://www.gov.uk/guidance/estate-regeneration-nationalstrategy. Accessed 2019 Mar 1.

28. ONS. Housing affordability in England and Wales: 2017. Available from: https://www.ons.gov.uk/peoplepopulationandcommunity/housing/bulletins/ housingaffordabilityinenglandandwales/2017\#housing-affordabilityworsened-the-most-in-london-over-the-last-five-years. Accessed 2019 Mar 1.

29. Van Kempen R, Dekker K, Hall S, Tosics I. Restructuring large housing estates in Europe. Bristol (UK): Policy Press; 2005. 
30. Smets P, Watt P. Social Housing and Urban Renewal: Conclusion. In Watt P, Smets P, editors. Social Housing and Urban Renewal. London (UK): Emerald Publishing; 2017. p. 459-78.

31. Lees L. The death of sustainable communities in London? In Imrie R, Lees L, editors. Sustainable London: The Future of a Global City. Bristol (UK): Policy Press; 2014a.

32. Lees L. The Urban Injustices of New Labour's “New Urban Renewal”: The Case of the Aylesbury Estate in London. Antipode. 2014b;46(4):921-47.

33. Elmer S, Dening G. The London Clearances. City. 2016;20(2):271-77.

34. Watt P, Minton A. London's housing crisis and its activisms. City. 2016;20(2):204-21.

35. IPPR. City Villages: More Homes, Better Communities. London (UK): IPPR; 2015.

36. Social Life. Design for Social Sustainability: A Framework for Creating Thriving New Communities. 2011. Available from: http://www.sociallife.co/media/files/DESIGN FOR SOCIAL SUSTAINABILITY 3.pdf. Accessed 2019 Mar 1.

37. Hollander, G. Rebuilding Soapsud Island, Inside Housing. Available from: https://www.insidehousing.co.uk/home/home/rebuilding-soapsud-island50197. Accessed 2019 Mar 1.

38. Countryside. Your Acton Gardens: FAQs. 2017. Available from: http://www.yoursouthacton.co.uk/. Accessed 2019 Mar 1.

39. L \& Q (London, UK). Internal private communication. 2017 May.

How to cite this article:

Dixon T, Bacon N, Arendar LC, Nielsen E, Callway R, Naylor A. Measuring the Initial Social Sustainability Impacts of Estate Regeneration: A Case Study of Acton Gardens, London. J Sustain Res. 2019;1:e190002. https://doi.org/10.20900/jsr20190002 